\title{
Does information matter? Transparency and demand for accountability in Ghana's natural resource revenue management ${ }^{1}$
}

\author{
Christa Brunnschweiler (University of East Anglia) ${ }^{2}$ \\ Ishmael Edjekumhene (KITE) ${ }^{3}$ \\ Päivi Lujala (NTNU and University of Oulu) ${ }^{4}$
}

28 October, 2019

\begin{abstract}
Transparency in resource revenue management is seen as an important strategy to avoid misuse and misappropriation. Theory predicts that transparency will allow citizens to gain information on revenue management; better informed citizens in turn will enter the debate on national resource governance issues, voice concerns, and demand improved accountability if necessary. However, there is little microlevel evidence on how transparency policies relate to better citizen knowledge, or to differences in attitudes towards revenue management and in demand for accountability. We analyze data from a unique survey of over 3500 Ghanaian citizens to understand how Ghana's extractive sector transparency measures are linked to citizens' knowledge, rights perception, satisfaction levels, and behavior regarding resource revenue management. Our results suggest that information levels among citizens are quite poor; however, there is a strong sense of citizens' right to benefit from resource revenues. Satisfaction with the status quo is very low; yet, few respondents have sought more information, or even discussed resource revenue management with friends or family. The results also hold for elected representatives, who should be best placed to influence resource governance. The findings imply that the transparency discourse hinges on false assumptions of the effects of information in resource revenue management.
\end{abstract}

Keywords: transparency; accountability; survey data; Ghana; natural resources; petroleum.

\footnotetext{
${ }^{1}$ We gratefully acknowledge useful comments and suggestions from Maarten Voors and seminar and conference participants at OxCarre (University of Oxford), UNU-MERIT, University of Orléans, and the TrAcRevenues Workshop at the Norwegian University of Science and Technology (NTNU). This work was supported by 3ie, the Research Council of Norway (grant no. 231757), the Academy of Finland (grant no 309206), and NTNU. The usual disclaimer applies.

${ }^{2}$ Corresponding author: c.brunnschweiler@uea.ac.uk, School of Economics, University of East Anglia (UEA), NR4 7TJ Norwich, UK.

${ }^{3}$ iedjekumhene@kiteonline.net, Kumasi Institute of Technology, Energy and Environment (KITE), P. O. Box AT 720, Achimota Market, Ghana.

${ }^{4}$ paivi.lujala@oulu.fi, Geography Research Unit, University of Oulu, Finland \& Department of Geography, Norwegian University of Science and Technology (NTNU), Trondheim.
} 


\section{Introduction}

Many developing countries heavily rely on their natural resource sectors to raise the revenues necessary to develop their economies and improve living conditions for their citizens. However, if not managed judiciously, their natural resource endowments can turn into a "resource curse", a phenomenon characterized by slow economic growth, weak political institutions, and even violent conflict (van der Ploeg 2011). The mismanagement of resource revenues has often been cited as a root cause of the resource curse, which thrives on opacity in resource revenue management. The promotion of transparency in revenue management is therefore frequently advised by the international community (Haufler 2010), or even made a prerequisite for obtaining aid, loans and investment from donors and extractive companies (David-Barrett and Okamura, 2016; Kasekende et al. 2016). The underlying assumption is that transparency will allow citizens to gain (more) information on their country's resource revenues and their management. Better informed citizens, in turn, will be able to contribute to a national debate on resource governance issues, voice their concerns, and demand more accountability from their governments when necessary (Epremian et al. 2016; Fox 2015; Gillies and Heuty 2011; Lujala and Epremian 2017). Ultimately, transparency would then lead to improved revenue management and public spending, and lower corruption levels.

This article addresses two crucial questions that arise from the theory of transparency: first, is transparency in fact linked to better-informed citizens? And second, is transparency linked to citizens' views on resource revenue governance and their related behavior? To understand these relationships, we make use of a unique national survey of over 3500 Ghanaians. The survey focused on citizens' knowledge levels on natural resource revenues - particularly petroleum and mining revenues - and the institutions that govern them; citizens' attitudes towards the current use of resource revenues, including their perception of politicians' and their own rights regarding resource revenue use; and citizens' willingness to seek more information and take action to influence how resource revenues are used.

Ghana provides an interesting case study: it has a long history of resource extraction, particularly in gold mining (Ghana being the second largest African gold producer after South Africa), and in 2007, it discovered offshore petroleum. Petroleum production began in 2010, and in 2011, the Ghanaian Parliament passed the Petroleum Revenue Management Act (PRMA, Act 815), which provides the framework for the collection, allocation and management of petroleum revenues in a responsible, transparent and accountable manner for the benefit of the citizens of Ghana. The PRMA and its associated institutions - the Public 
Interest Accountability Committee (PIAC, an independent public oversight body), the Annual Budget Funding Amount (ABFA, which receives and allocates $70 \%$ of the petroleum revenues to development projects throughout the country), and the Stabilization and Heritage funds have been viewed as model attempts to provide transparency and accountability in resource revenue governance. Ghana has since 2003 also participated in the Extractive Industries Transparency Initiative (EITI), the most widely implemented and supported transnational transparency initiative within natural resource governance.

Several years have passed since joining the EITI and the implementation of the PRMA, so it is time to take stock of the situation and see whether the efforts at transparency have borne fruit. Previous studies suggest that citizens in communities close to Ghana's offshore oil fields have little knowledge of the petroleum sector and its revenue management (Ofori and Lujala 2015), and that even members of the District Assemblies - the main tier of the decentralized governance structure in Ghana - have poor access to general information and make policy decisions based on memory and experience (Fiankor and Akussah 2012). ${ }^{5}$

Our basic hypothesis is that better-informed respondents are more assertive about their rights and take more action for accountability. The main channel is assumed to be a weakening of the perceived barriers to action (i.e., the "voice" option becomes cheaper, see Hirschman 1970). We have no definite prior on how knowledge levels affect satisfaction with the status quo; but we do expect that respondents with more assertive attitudes and lower satisfaction with the status quo take more action because they are more motivated to do so. We expect elected representatives at lower administrative levels - the District Assembly and Unit Committee members - to have especially high incentives to monitor the management of resource revenue, as it potentially directly affects their constituencies. ${ }^{6}$ Finally, we expect that individuals with higher education levels are more able and thus more likely to demand accountability (Kolstad and Wiig 2009).

We find some encouraging results regarding the relation between information on revenue use and individual behavior, suggesting that better knowledge levels are linked to the frequency at which these issues are discussed informally, and the number of times citizens contact someone to gain more information. Education levels have a sportive link with both knowledge levels and our behavioral outcomes. At the same time, our results also make it clear that there

\footnotetext{
${ }^{5}$ Ghana's decentralized governance structure has three main tiers: the Regional Councils at the top; the District Assemblies - shorthand for Metropolitan, Municipal and District Assemblies - in the middle; and the Unit Committees at the bottom. The most power in this system rests with the District Assemblies (FES 2016).

${ }^{6}$ We consequently oversampled these elected representatives in our survey in order to have enough statistical power.
} 
is much room for improvement both in disseminating information relating to resource revenue use, and in encouraging citizens - and elected leaders - to voice their concerns. Finally, we find no discernible difference between information on or satisfaction with the management of petroleum revenues and mining revenues, perhaps because most citizens do not clearly differentiate the two.

The paper proceeds as follows. Section 2 discusses the theory of transparency; Section 3 briefly describes how Ghana manages its resource revenues and transparency's role in it; Section 4 explains the survey data and empirical methodology; Section 5 presents the main results; and Section 6 concludes.

\section{The theory of transparency}

There is no commonly agreed definition of transparency. Transparency can be defined narrowly as "the increased flow of timely and reliable economic, social and political information which is accessible to all relevant stakeholders" (Bellver and Kaufman 2005, p. 4), or broadly as "the degree to which information is available to outsiders that enables them to have informed voices in decision and/or to access the decisions made by the insiders" (Florini 2007, p. 5). The narrow definition of transparency restricts the concept to information disclosure, whereas the broader definition goes beyond mere disclosure to look at the ability of the receiver to assimilate, process and utilise the information made available (Epremian et al. 2016). Although transparency has some intrinsic value, the term has been popularized largely by its instrumental value, i.e. as a means to an end: according to Buijze (2013, p.4), transparency is desirable "because it promotes democracy, trust in public institutions, or market efficiency".

Theories of transparency often predict that increased information disclosure will catalyse a series of (necessary) stages along a causal chain ending in improved governance (Epremian et al, 2016; Fenster, 2015; Heald, 2006a; Lujala and Epremian, 2017). Fung (2007) and Kosack and Fung (2014) describe the transparency action cycle as a process begun by (1) state institutions' provision of salient and accessible information to citizens about practices and policies; followed by (2) citizens receiving and (3) acting on the information, seeking to influence the state; (4) the state institutions finding the citizen action and feedback salient; and (5) state institutions responding constructively through changing practices and policies. The loop is finalized by (6) the state providing updated information to the public about the changes it has made to practices and policies for further evaluation. 
The transparency process may break down in any one of these phases. In this article, we focus on the links between phases (2) and (3) in the chain. Specifically, we analyse how the provision of information through the transparency initiatives in Ghana relates to knowledge levels, attitudes and behavior of the citizenry towards revenue management.

The role of information in influencing behavioral outcomes is based on standard economic assumptions of rational choice theory, which results in linear models of behavior. But does information on natural resource revenues in fact relate to knowledge levels, and - given knowledge levels - to attitudes and behavior of the citizenry towards the management of revenues? Intuitively, for behavioral changes to take place, citizens must not only receive information, but also care about the policy in question, and have feasible and well-known ways of acting on the information. Kolstad and Wiig (2009: 529) summarize the issues by stating that "[a]gents whose access to information is increased, must also have an ability to process the information, and the ability and incentives to act on that information. The impact of transparency therefore depends on the level of education of an electorate, [and] the extent to which key stakeholders have the power to hold a government to account". Accordingly, the current paper pays particular attention to the leadership status and educational level of individual respondents in the analysis.

We focus on short-term and intermediate outcomes as there exists little rigorous empirical research on the relation of natural resource revenue-related information to knowledge levels, attitudes and behavior of the citizenry (see Lujala and Epremian 2017). Armand et al. (2018) evaluate the impact of a large information campaign relating to natural gas discovery on knowledge, awareness, elite capture, rent-seeking and citizen mobilization, trust and accountability in northern Mozambique. They implemented a large-scale randomized field experiment and found, among others, that a community-targeted information campaign was effective in raising awareness and knowledge of citizens; that information given to leaders increased elite capture and rent-seeking; and that providing the general population information and the opportunity for deliberation increased mobilization, trust, and voice, and decreased violence. Our paper provides further real-world evidence and helps deepen understanding about how information disclosure regarding natural resource revenues is linked to knowledge, attitudes and behavior of citizens and duty bearers.

\section{Ghana's natural resource revenue management}

Ghana is endowed with substantial mineral resources. Commercially exploited minerals in Ghana include gold, manganese, bauxite, diamonds and, more recently, hydrocarbons. Ghana's 
mining sector played a significant role in the socio-economic development of the country during the colonial and post-colonial eras. Not only has the mining sector consistently been the highest gross foreign exchange earner in Ghana for most of the past three decades, but it is also the largest tax-paying sector in the country and makes a significant contribution to GDP (Ministry of Finance 2018).

Until the discovery of oil and gas in commercial quantities in 2007, gold was by far the economically most important mineral resource, contributing over $90 \%$ of the country's total mineral revenue. However, despite the substantial revenues generated by the mining sector, Ghana has had very little to show in terms of social and economic development. For example, Ayee et al. (2011) describe the disappointingly small contribution of mining to the overall development of the national economy, while Adusei (2008) points to the deplorable state or even absence of physical infrastructure and social amenities in mining communities, concluding that environmental costs are the main effect these areas have seen. According to the World Bank (2003), local communities affected by large-scale mining had witnessed little benefit in the form of improved infrastructure or service provision, because most of the rents from mining are used to finance recurrent, not capital expenditure.

Ghana's failure to translate the massive mineral wealth earned over the past century into broad-based and inclusive economic development, coupled with the significant environmental degradation caused by mining, created a lot of skepticism and despondency among citizenry at the time oil was discovered. With gold largely deemed a "lost cause", there was a national consensus and resolve to ensure that Ghana would manage its oil resources better than its mining resources. Consequently, the Parliament of Ghana passed the PRMA in 2011, designed to guide the collection, allocation and management of petroleum revenues. The development of the Act was informed by four main guiding principles: 1) To ensure the availability of additional revenue to support the national budget; 2) To minimize potential negative effects on the management of the economy in general and on public spending in particular; 3) To maximize transparency and accountability in collection, management and use of petroleum revenue; and, 4) To provide savings for future generations.

Point 1 is mainly captured by the funds allocated to the ABFA; however, although used for development projects across the country, the funds have generally contributed only part of the overall financing of any one project, and it is unclear whether the local population is aware of the use of petroleum money in their area (Edjekumhene et al. 2018).

Point 3 is of particular relevance for the present analysis. The PRMA imposes on state institutions mandatory periodic reporting in their management of petroleum receipts and 
expenditure. The Act also stipulated the establishment of PIAC, which is responsible for ensuring compliance with the Act. Among other responsibilities, PIAC is to engage with citizens to increase knowledge and awareness of petroleum revenue management, and to monitor and improve citizen's capability and willingness to hold the government accountable in managing and spending petroleum revenues. PIAC is required by the Act to publish two reports per year - a semi-annual report due by September 15 and an annual report due by March 15 of every year - and is mandated to actively create a platform to gather citizens' comments and present them to Parliament and the Presidency along with their reports. So far, PIAC has published thirteen reports - six semi-annual and seven annual reports. It has regularly presented and discussed these reports before Public Accounts and Finance Committees of Parliament. The Committee has also occasionally travelled to regional and district capitals to hold public information meetings.

Apart from the PMRA, the management of Ghana's natural resource revenues is also subjected to the EITI principles, which Ghana signed up to as one of the pilot countries in 2003 at the first EITI meeting in London, becoming an EITI compliant country in 2010. ${ }^{7}$ Although, the scope of Ghana EITI (GHEITI) was limited to revenue transparency in the beginning, the current EITI Standards require vastly broader information disclosure, covering areas such as production volumes, export data, revenue management, quasi-fiscal expenditures, and recommended disclosure of contracts and beneficial ownership, through the annual EITI reports and other means (EITI 2016). In Ghana, plans are afoot to legislate the EITI into law and a draft EITI Bill is currently before the Ghanaian Parliament for consideration and passage into an Act.

Thus, the provision of information on revenues from Ghana's mining and oil and gas sectors and their utilization has been the bedrock of the GHEITI and the PRMA. But have they resulted in a population that is well-informed about resource governance and that is willing to take action to demand accountability?

\footnotetext{
${ }^{7}$ To become 'EITI compliant', a country needs to pass a validation that assesses it against the requirements set by the EITI Standard (EITI 2016). The annual EITI Report is the core EITI product. It contains the data on the country's extractives industries in accordance with the EITI Standard (see https://eiti.org/document/guidancenote-on-publishing-eiti-data). For a more detailed account of how the EITI came into existence, how it functions, and what its objectives are, see Haufler (2010), Öge (2016), Van Alstine (2017) and Lujala (2018). For a recent overview of the literature on the EITI's impact, see Rustad et al. (2017).
} 


\section{Data and empirical methodology}

We use a unique dataset based on a large survey carried out in June-August 2016 by the Kumasi Institute for Technology, Energy and Environment (KITE) in Ghana. ${ }^{8}$ The purpose of the survey was to study people's level of knowledge of and perceptions and attitudes towards a number of petroleum and mining revenue management related issues, and to study how people inform themselves about these issues and what action they have taken to influence resource revenue management either locally or nationally. The survey sample consists of 3526 adult (18 and over) respondents. The respondents were interviewed face-to-face by locally recruited enumerators.

A combination of blocking and clustering was used in sampling: first, 120 of Ghana's 216 districts were selected, including all coastal districts close to the offshore petroleum platforms (termed "oil districts") and 25 mining districts. The remaining 89 districts were randomly selected with probability proportional to population size. The districts included in the survey are shown in Figure 1. Second, five electoral areas were randomly chosen in each selected district. One District Assembly member (DA) per electoral area was randomly selected from a list obtained from the District Administration. The selected DA was contacted and an appointment made to meet in their electoral area; in addition, each DA was asked to suggest one Unit Committee (UC) member; one chief or other prime member of the traditional authority such as a Queen Mother; and one other opinion leader (e.g., a journalist) in their electoral area. ${ }^{9}$ Lastly, two ordinary citizens ( 1 male and 1 female) were randomly selected in each electoral area. ${ }^{10}$ The sampling structure therefore targeted 30 respondents per selected district, with an average 26 respondents per district included in the survey. The coastal districts close to offshore petroleum production areas, and the districts with mining operations, were oversampled, as were local leaders in each electoral area. Due to gender structures in Ghana, women are underrepresented among the decision makers, but women make up $50 \%$ of the common citizens' sample by design.

\footnotetext{
${ }^{8}$ The survey is part of a field experiment conducted between June 2016 and September 2017.

${ }^{9}$ In case a UC member, traditional authority or other opinion leader could not be reached, another opinion leader was added instead. The non-random selection of these duty bearers was chosen as there are no reliable lists available.

10 Two enumerators first agreed on who would interview a male and female respondent, alternating respondent gender across electoral areas. Then the two enumerators each went in two opposite directions, counting 100 steps from the spot where the team met the DA, ensuring that electoral area borders were not crossed; then, the closest person of the selected gender willing to participate in the survey was interviewed.
} 


\subsection{Dependent variables}

In our analysis, we use three sets of dependent variables: one for knowledge levels, one for attitudes towards oil and gas and mining revenue management, and one for individual behavior. $^{11}$

Knowledge. We measure current knowledge levels with three different proxies. The first one includes answers to the questions on whether the respondent had received information within the past twelve months on how oil, gas or mining revenues are handled in Ghana and in their area, with yes (coded as 1) and no (coded as 0 ) as the answer alternatives. ${ }^{12}$ National-level information on oil, gas or mining revenues was relatively low $30.8 \%$ had received information), and local-level information very low (6.7\%); overall, $31.4 \%$ had received information at some level.

Our second knowledge measure is a count variable from 0 to 4 for whether the respondent had heard of one or more of the following: the GHEITI, PRMA, ABFA, and PIAC. Respondents overwhelmingly said they had not heard of the PRMA (63\%), the ABFA (87\%), the GHEITI (95\%), or PIAC (77\%). ${ }^{13}$

Our final knowledge measure gauges individuals' self-assessed knowledge about what happens to revenues from oil and gas production and from mining. The answers are measured on a four-point scale going from 0 (No knowledge) to 3 (Good knowledge). Around 67\% of respondents admitted to having no knowledge about oil and gas or mining revenue management, around $32 \%$ said they had some knowledge; and a meagre $1.3 \%$ claimed to have good knowledge of at least one of two revenue types. Women were always more likely to report less knowledge than men. Differences in knowledge levels between the resource types were minimal and the correlation between the two variables is 0.84 .

\footnotetext{
${ }^{11}$ Table A1 in the Appendix reports summary statistics, full survey question(s) and answer alternatives for each variable used.

${ }^{12}$ We initially look at local and national level information reception separately as well as the overall measure, but then concentrate on the combined measure. For all variables, missing answers and answers "I do not know" or "I do not want to answer" were dropped.

${ }^{13}$ Note that these questions were based on respondents' self-assessment. Of the few (mostly male) respondents who said they had heard of these institutions, less than half were able to describe them (partly) correctly when asked to do so.
} 


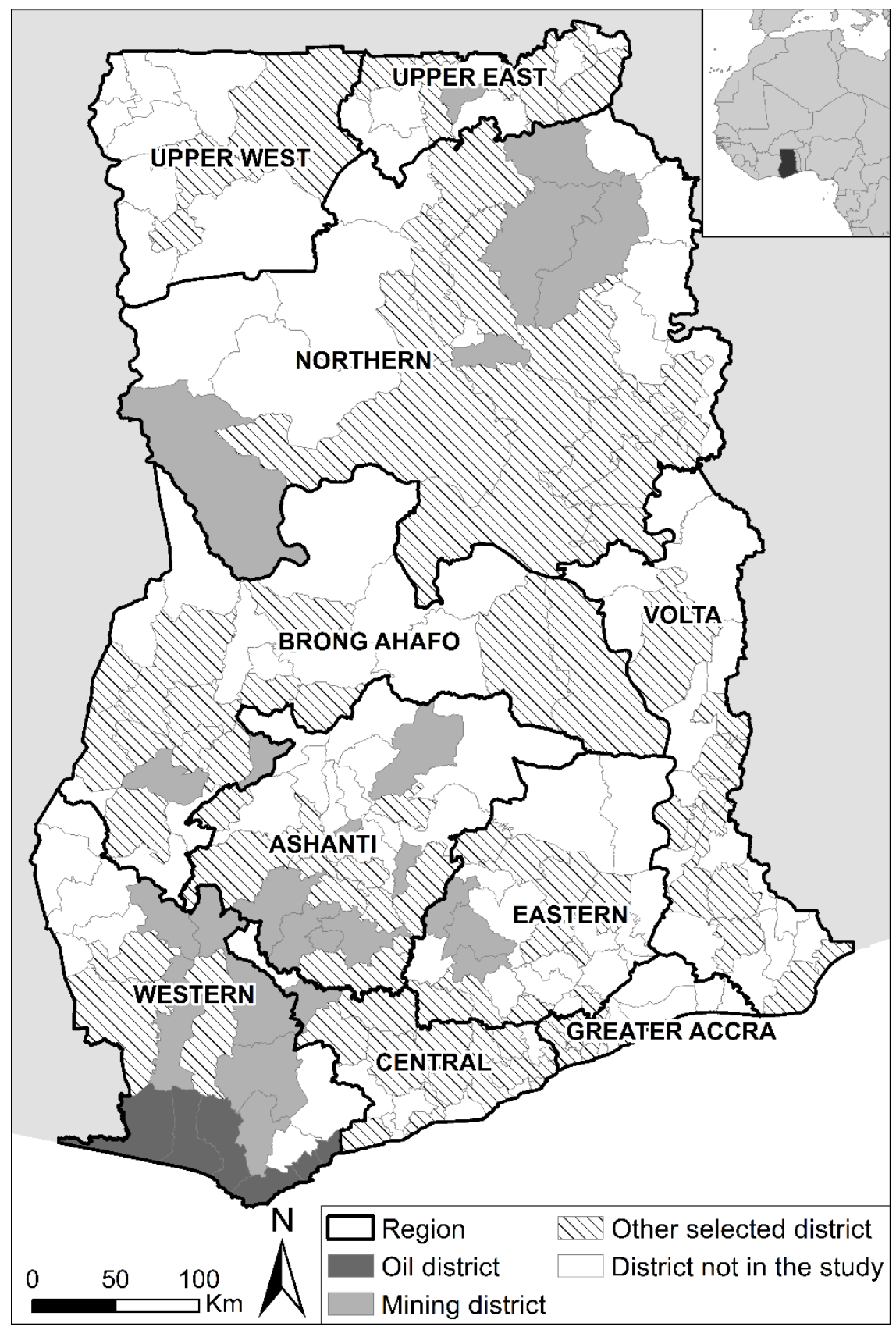

Figure 1. Map of Ghana showing survey districts.

Attitudes. We measure attitudes by including respondents' (1) satisfaction levels with the current handling of oil and gas or mining revenues, and (2) perception of citizens' rights regarding resource revenue management. We measure satisfaction with oil and gas revenue and mining revenue management, respectively, using a five-point Likert scale from 0 (completely dissatisfied) to 4 (completely satisfied). Seventy six percent (76\%) of respondents express dissatisfaction with the handling of oil and gas revenues, and $78 \%$ are dissatisfied with the handling of mining revenues. We also measure attitudes regarding local elected politicians' and traditional leaders' right to receive a share of resource revenues as compensation for their 
services: interestingly, only $23 \%$ completely disagree that neither of these authorities should receive a share of revenues, and $28 \%$ completely agree that both groups have the right to receive a share of the revenues as a compensation. Respondents have strong views regarding their rights to benefit from revenues, demand information, and demand better handling of revenues: $99 \%$ agree that they have the right to benefit from resource revenues; $95 \%$ agree that they have the right to demand relevant information; and $96 \%$ agree that they have the right to demand better handling of revenues. All three variables are measured on a five-point Likert scale going from 0 (completely disagree) to 4 (completely agree).

Behavior. The third and final set of dependent variables measures individual behavior: we asked respondents whether in the previous year they had discussed the usage of oil, gas or mining revenues with friends, family or colleagues. This is a low-level indicator of active citizen interest in resource revenue management, yet only $21 \%$ (717) of respondents answered in the affirmative. To measure more costly citizen engagement, we then inquired whether they had contacted anyone over the previous year to ask about the handling of resource revenues, and only $6.4 \%$ (224) told us they had. ${ }^{14}$ Both variables are coded as dummies with 'yes' taking the value of 1 . In addition to these general behavioral questions, we asked DA and UC members and traditional leaders specifically about how many times in the past year they had discussed revenues from oil, gas or mining in meetings with their peers. The variables take value of 0 for 'Never', 1 for 'Once', 2 for '2-3 times' and 3 for 'more than 3 times'. 95\% (572) of UC members, $92 \%$ (515) of DA members, and 87\% (334) of traditional leaders had never discussed the issue with their peer leaders.

Overall, we get a picture of poor levels of knowledge regarding resource revenue management, yet high levels of dissatisfaction with the status quo, and very little active interest in revenue management, with hardly any difference between the recent oil and gas revenues and the long-existing mining revenues. In order to devise a better way of disseminating information on resource revenues, particularly oil and gas revenues, and making transparency matter for the average citizen and the local leaders, we need to understand which factors are linked to each of our outcomes, i.e. include a set of relevant control variables. Variation in most outcomes we use is low, which makes the task particularly challenging.

\footnotetext{
${ }^{14}$ The most popular contacts cited were a District Assembly member (48.4\% or 106 respondents); a non-elected local official (31.5\% or 70); a Unit Committee member or a traditional leader (both contacted by $28 \%$ or 62 respondents); and an MP (25.5\% or 57$)$.
} 


\subsection{Explanatory variables}

Our individual-level controls include gender; education levels; information access (i.e., personal or household ownership of a radio, television, or mobile phone), ${ }^{15}$ general interest in political and public affairs; and general satisfaction with government. Note that education levels and media ownership can also be interpreted as proxies for income levels. In the context of our survey, we also add a dummy variable for whether any mining or oil company operated in or near the respondent's area, based on the premise that being close to a resource production site increases the local population's awareness of resource revenues management. ${ }^{16}$ Furthermore, we include a dummy for whether the respondent was a DA or UC member, traditional leader, or other opinion leader, the common citizen group being the reference category.

We include dummies for (mostly) urban districts, as well as regional dummies. In some estimations, we use the outcome variables for Knowledge as controls, ${ }^{17}$ in others we also control for the general level of satisfaction with government. Finally, we control for different potential reasons for passivity by including variables that measure respondent's agreement with statements on revenue management not being their responsibility, being afraid of reprisals, and not receiving information even if they had demanded it.

\subsection{Methodology}

To test the hypotheses described above, we examine in turn which factors are linked with each of our three sets of dependent variables. We show results from OLS regressions for all dependent variables $y$ for respondent $i$ in district $d$ according to the following model: ${ }^{18}$

$$
y_{i d}=a+\alpha b_{r}+\beta_{1} X_{i d}+\beta_{2} V_{d}+\varepsilon_{i d},
$$

where $X$ and $V$ are vectors of the control variables at the individual level and district level, respectively; $b$ is a dummy variable for region $r ; a$ is the constant term; and $\varepsilon$ is the error term.

We include sampling weights to correct for the oversampling of local leaders, males, and higher income households. We also include information about the sampling design - the blocking, clustering and stratification - in our analysis. In the first stage, we sampled districts

\footnotetext{
${ }^{15}$ We also asked about ownership of or access to other types of information media such as newspapers or internet, but these were much less frequent.

${ }^{16}$ We alternatively included a dummy for oil or mining districts, but this was only significant in the specifications relating to leaders' behaviour, so we prefer using the more localized information on resource production in a respondent's local area in all estimations.

17 The variable on knowledge of institutions has been collapsed to a dummy that takes the value of 1 if the respondent had indicated to know at least one revenue management related institution.

${ }^{18}$ We show the corresponding results for logistic and ordered logistic regressions in Appendices 2-6. The results mirror closely the OLS regression results, the few exceptions are noted in the text.
} 
and thus we use districts as our primary sampling unit. The variance estimates are calculated using the three strata (oil districts, mining districts and all the other districts) and the total stratum sizes with the finite population correction. At the second stage, as each district includes a different number of electoral areas, we adjust the variance estimates by including total number of electoral areas in finite population correction. Standard errors are estimated using Taylor linearized variance estimation. ${ }^{19}$

\section{Estimation results}

We analyse each of our three dependent variable categories - knowledge, attitudes and behavior - in turn. For ease of interpretation and space reasons, we present summary tables of results for our outcome and main explanatory variables, with only coefficient signs and significance levels. Detailed OLS results can be found in the Supplementary Appendix Tables SA1-5, and corresponding results for logit and ologit estimations in Tables SA6-10.

\subsection{Knowledge levels}

In Table 1, we first look at respondents' information reception (Columns 1-3) about oil, gas or mining revenue management and then their knowledge levels about institutions related to oil and gas revenue management (Column 4) and petroleum and mining revenue management (Columns 5 and 6, respectively). Column 1 shows that respondents who indicated that there was oil or mining production in their local area and those with a radio in their household were more likely to have received any information during the previous year on how revenues from oil, gas or mining are handled, though the coefficient magnitudes remain below 10 percent. Education levels also have a strong though limited-in-size positive link with information reception, as does general political interest. We further find that while gender plays no role, the respondent's role in society does matter: DA members, traditional leaders and other opinion leaders are much more likely overall than common citizens to have received information.

There are some noteworthy differences between national-level (Column 2) and local information (Column 3) about the handling of oil, gas or mining revenues: education and political interest levels do not influence local information reception, and traditional leaders are no more likely to have received local information than common citizens. UC and DA members

19 The three subsamples of UC and DA members, and traditional leaders, are analysed without weighting to account for the substantial differences with regard to the rest of our sample population. The DA and UC member subsample estimations use a one-step clustering approach, while the traditional leader subsample estimations use no stratification at all due to issues with singleton strata (i.e. some clusters have no or only one respondent from this subsample). Anonymized replication data file and detailed replication instructions will be made available upon publication of the article. STATA 15.1 was used in the analysis. 
Table 1. Knowledge of resource revenues and institutions

\begin{tabular}{|c|c|c|c|c|c|c|}
\hline & $\begin{array}{l}\text { Information } \\
\text { on oil and } \\
\text { mining in } \\
\text { Ghana or in } \\
\text { own area } \\
\text { (1) }\end{array}$ & $\begin{array}{l}\text { Information } \\
\text { on oil and } \\
\text { mining in } \\
\text { Ghana } \\
(2)\end{array}$ & $\begin{array}{c}\text { Information } \\
\text { on oil and } \\
\text { mining in } \\
\text { own area } \\
\text { (3) }\end{array}$ & $\begin{array}{c}\text { Knowledge } \\
\text { of } \\
\text { institutions } \\
\text { (4) }\end{array}$ & $\begin{array}{c}\text { Knowledge } \\
\text { of oil } \\
\text { revenues } \\
\text { (5) }\end{array}$ & $\begin{array}{c}\text { Knowledge } \\
\text { of mining } \\
\text { revenues } \\
(6) \\
\end{array}$ \\
\hline Female & - & - & - & $----* * *$ & $-* * *$ & $-* * *$ \\
\hline Urban district & - & + & - & + & + & + \\
\hline Education level & $+* * *$ & $+* * *$ & + & $+* * *$ & $+* * *$ & $+* * *$ \\
\hline $\begin{array}{l}\text { Oil or mining } \\
\text { nearby }\end{array}$ & $+* * *$ & $+* * *$ & $+* * *$ & $+^{*}$ & $+^{*}$ & $++* * *$ \\
\hline Radio ownership & $+* * *$ & $+* * *$ & $+* * *$ & $+*$ & $+* *$ & $+* * *$ \\
\hline TV ownership & + & + & $+*$ & $+^{*}$ & + & $+* * *$ \\
\hline $\begin{array}{l}\text { Mobile phone } \\
\text { ownership }\end{array}$ & - & - & - & + & + & + \\
\hline Political interest & $+* * *$ & $+* * *$ & + & $+* *$ & $+* * *$ & $+* * *$ \\
\hline $\begin{array}{l}\text { District Assembly } \\
\text { member }\end{array}$ & $++* * *$ & $++* * *$ & $+* *$ & $++* * *$ & $+++* * *$ & $+++* * *$ \\
\hline $\begin{array}{l}\text { Unit Committee } \\
\text { member }\end{array}$ & + & + & $-* * *$ & $+*$ & $+* *$ & $+* * *$ \\
\hline Traditional leader & $+++* * *$ & $+++* * *$ & + & $++* * *$ & $++* * *$ & $+++* * *$ \\
\hline Opinion leader & $+* * *$ & $+* * *$ & $+* * *$ & + & $++* * *$ & $++* * *$ \\
\hline
\end{tabular}

Notes: Overview of results of OLS estimations, including regional dummies and a constant term (not shown).

Table shows coefficient signs and levels of significance. One +/- denotes (absolute) coefficient magnitude from zero to 0.099; two +/- a coefficient magnitude from 0.1-0.199; three -/+ a coefficient magnitude from 0.2 upwards. $* * * p<0.01, * * p<0.05, * p<0.1$. Detailed results can be found in Appendix Table A2.

are slightly less likely to have received information about how resources revenues are managed in their area than common citizens. A plausible explanation for this seemingly counterintuitive finding lies in the very low outcome variation described above, so it may be spurious.

Column 4 explores the factors related to self-expressed knowledge levels about the institutions related to resource revenue management and columns 5-6 the management of petroleum and mining revenues, respectively. We see that women generally claim lower knowledge levels, particularly when it comes to the specific institutions of the PRMA, ABFA, GHEITI, and PIAC in column $4 .{ }^{20}$ More educated respondents, all types of local leaders, and politically more interested respondents are more likely to profess greater knowledge of institutions, and of the management of oil and gas and mining revenues (Columns 5-6), as are those respondents with a radio or TV in the household, and with oil or mining nearby. ${ }^{20}$ Recall that these subjective knowledge assessments are not necessarily a true indicator of actual knowledge, as
demonstrated by the limited overlap between professed and actual knowledge of institutions mentioned above. 


\subsection{Attitudes towards resource revenue management}

Column 1 in Table 2 report the results for satisfaction with the handling of oil and gas revenues, and column 2 for satisfaction with the handling of mining revenues. A general tendency is that factors affecting the satisfaction levels for both types of revenues go in the same direction. The only detectable difference is mobile phone ownership, which is linked to slightly lower satisfaction with oil and gas revenue management, but has no relation with mining revenues. The presence of an extractive industry company in the area has a negative effect on satisfaction levels, as has radio ownership (TV has a similar, but even weaker effect). Those who are more engaged with political issues also view current revenue management more critically.

Knowledge about resource revenue management does not affect respondents' satisfaction levels; but those who tend to be more satisfied with the government in general are considerably more likely to be satisfied with how resource revenues are being handled. Women report slightly higher satisfaction levels. ${ }^{21}$

Further, the results indicate that the elected local leaders and other opinion leaders tend to be more satisfied with revenue management than common citizens. The traditional leaders may be less satisfied as indicated by the negative coefficients (which, however, are not significant at conventional levels). It is noteworthy that education level does not affect satisfaction levels, and that there is no urban-rural divide.

Columns 3-6 present the results for respondents' perceptions on their rights with regard to natural resource revenues. Column 3 reports the results for the respondents' perception on whether local politicians have a right to a share of resource revenues as a compensation for their services; column 4 shows respondents' perception of their own right to benefit from revenues; column 5 of the right to demand more information; and column 6 the right to demand better handling of revenues.

Those with a higher level of education clearly do not support the idea that local leaders have the right to take a share of revenues as compensation for their services. They are also more likely to assert that they have the right to obtain more information about, and better handling of, resource revenues. There is some evidence that education levels are related to higher expectations regarding the right to benefit from the revenues. ${ }^{22}$ Women are more likely to

\footnotetext{
${ }^{21}$ The ordered logistic estimations produce somewhat stronger results for women, indicating that women may be in general more satisfied with how mineral resource revenues are handled (Table SA7, Columns 4-6).

22 The coefficients are significant at $0.12<p<0.15$ level in the OLS estimations (Table SA3, Columns 4-6) and at $0.08<p<0.15$ in ordered logistic estimations (Table SA8, columns 4-6).
} 


\begin{tabular}{|c|c|c|c|c|c|c|}
\hline & \multirow[b]{2}{*}{$\begin{array}{l}\text { Satisfaction } \\
\text { with oil } \\
\text { revenue } \\
\text { management } \\
\text { (1) }\end{array}$} & \multirow[b]{2}{*}{$\begin{array}{l}\text { Satisfaction } \\
\text { with mining } \\
\text { revenue } \\
\text { management } \\
(2)\end{array}$} & \multicolumn{4}{|c|}{ Perception regarding... } \\
\hline & & & $\begin{array}{l}\text { Local } \\
\text { leaders' } \\
\text { right to } \\
\text { benefits } \\
\text { (3) }\end{array}$ & $\begin{array}{l}\text { Own } \\
\text { right to } \\
\text { benefits } \\
(4)\end{array}$ & $\begin{array}{c}\text { Right to } \\
\text { demand } \\
\text { information } \\
\text { (5) }\end{array}$ & $\begin{array}{c}\text { Right to } \\
\text { demand } \\
\text { better } \\
\text { handling } \\
(6)\end{array}$ \\
\hline Female & $+*$ & $t^{*}$ & - & - & $++* * *$ & $--* * *$ \\
\hline Urban district & - & + & + & + & - & - \\
\hline Education level & + & + & $-* * *$ & + & $+* * *$ & $+* * *$ \\
\hline Oil or mining nearby & $--* *$ & $--* *$ & + & $+^{*}$ & - & + \\
\hline Radio ownership & ---* & $-*$ & $+++* *$ & $-* * *$ & $--* * *$ & $--* *$ \\
\hline TV ownership & $--*$ & - & - & - & + & + \\
\hline Mobile phone ownership & $---*$ & + & - & + & + & + \\
\hline Political interest & $-* * *$ & $-* * *$ & $-* * *$ & $+* *$ & + & $+*$ \\
\hline District Assembly member & ++ & $++^{*}$ & ++ & $+* *$ & $++* * *$ & $+* * *$ \\
\hline Unit Committee member & $+++* *$ & $+++* * *$ & $+++* * *$ & + & $++* * *$ & $++* * *$ \\
\hline Traditional leader & - & - & $+++* * *$ & $+* * *$ & - & - \\
\hline $\begin{array}{l}\text { Opinion leader } \\
\text { Received information on } \\
\text { revenue management }\end{array}$ & $+++* * *$ & $+++* * *$ & - & - & - & - \\
\hline $\begin{array}{l}\text { Knowledge of institutions } \\
\text { (dummy) }\end{array}$ & - & - & $+++* * *$ & - & $+* * *$ & $+* * *$ \\
\hline $\begin{array}{l}\text { Knowledge of revenue } \\
\text { management }\end{array}$ & + & + & - & - & $-* *$ & $-* * *$ \\
\hline Satisfaction with governmen & & & & & & \\
\hline & $+++* * *$ & $+++* * *$ & $+* *$ & $+* * *$ & + & + \\
\hline
\end{tabular}

Notes: Overview of results of OLS estimations, including regional dummies and a constant term (not shown).

Table shows coefficient signs and levels of significance. One +/- denotes (absolute) coefficient magnitude from zero to 0.099; two +/- a coefficient magnitude from 0.1-0.199; three -/+ a coefficient magnitude from 0.2 upwards. *** $p<0.01, * * p<0.05, * p<0.1$. Detailed results can be found in Appendix Tables A3-A4.

report weaker perceptions of their rights to demand more information about and better handling of revenues, but gender does not seem to affect views on local leaders' having the right to a part of the revenues, nor respondents' sense of their own right to benefit from revenues. Respondents living in areas with an extractive company are slightly more likely to report having the right to benefit from revenues. ${ }^{23}$

Those with a radio are more supportive of the idea that local leaders have a right to a share of revenues, and radio ownership decreases the likelihood of a respondent feeling the right to

\footnotetext{
${ }^{23}$ This result is insignificant in ordered logistics estimations (Table SA8, columns 4-6).
} 
benefit themselves or to get more information and better handling of revenues. This significant variation is remarkable given that over $90 \%$ of respondents have a radio in their household. We know that radio is the main source of information for people in Ghana (Lujala et al. 2018); the type of information received may be influencing rights perceptions, but an analysis of media content is beyond the scope of this paper. TV and mobile phone ownership do not seem to be related to rights perceptions. Those who more often discuss political issues are less likely to accept that local leaders take a share of the revenues, and there is some evidence that they are more aware of their rights, especially when it comes to the right to expect a better handling of resource revenues. ${ }^{24}$

UC members and traditional leaders are considerably more likely to state that local leaders have a right to a share of revenues, while the views of DA members and other opinion leaders are more similar to those of common citizens. Compared to common citizens, the DA members and traditional chiefs are more inclined to claim a right to benefit from the revenues themselves, and DA and UC members are more likely to report having the right for more information about and better handling of revenues.

Finally, those with knowledge of the PRMA, ABFA, GHEITI or PIAC more often accept local leaders' taking a share of the revenues, while also having a stronger sense of rights with regard to getting more information and better handling of revenues - this appears contradictory. Higher levels of knowledge of revenue information, on the other hand, are related to a lower sense of rights to more information and better handling. Those who are more satisfied with the government are more likely to accept the local leaders' taking a share of revenues and also think that they have a right to benefit from revenues themselves. ${ }^{25}$

\subsection{Behavior}

Table 3 shows the results for our behavioral outcomes. Our main measures of behavior are whether the respondent discussed the use of resource revenues with friends, family or colleagues in the past year (column 1), and whether they contacted someone to specifically ask about revenue handling in the same period (column 2), and whether leaders in particular discussed the issue with their peers in the past 12 months (columns 3-5). The first measure has a very low threshold for action, while the others have a higher threshold, especially making the effort to contact someone; together, they should give us a good picture of who has sought or is

\footnotetext{
${ }^{24}$ The ordered logistic estimations suggest also that these respondents are more likely to report a higher level of right to benefit from natural resource revenues (Table SA8, Columns 4-6).

25 The ordered logistic estimations suggest that these respondents are also more likely to report a higher sense of rights to more information and better handling (Table SA8, Columns 9 and 12).
} 
potentially willing to seek more information on petroleum revenue management. We include survey participants' rights perceptions and perceptions on meaningfulness of trying to influence resource revenue management as additional independent variables.

The results in Table 3 show that higher education levels and the presence of oil or mining activities nearby are positive predictors of behavior, as are general political interest, and whether or not the respondent was a duty bearer (elected or traditional authority) or opinion leader. Having ready access to a source of information in the form of a radio increases the likelihood of discussing the issues, but not of contacting someone. The results also suggest a positive relationship between living in an urban district and being more likely to discuss the issues. $^{26}$

Encouragingly, we see that those who are better informed about resource revenue governance and on what is going on in the sector are much more likely to report both discussing the issues and contacting someone regarding the use of revenues. The magnitude of the relationship lies well above 10 percent on average for knowledge (see Table A5), which is encouraging.

Curiously, respondents who are more supportive of the right of local leaders to retain a share of revenues as compensation for their services are also slightly more likely to discuss revenue-related issues and more likely to contact someone. Perception of respondents' own rights instead plays no role in explaining behavior. ${ }^{27}$ Finally, we note that fear of potential reprisals and a sense of pointlessness to any effort in this context reduce the likelihood of discussing the issues, though the size of the link is small; while the sense that it is not the respondent's responsibility to become involved in revenue management surprisingly increases discussion.

We also asked duty-bearers and the chiefs in particular whether they had discussed the use of resource revenues during meetings with their peers over the past 12 months. Recall that we expect these respondents to have the greatest incentive to be informed about resource revenues due to their positions of authority, to influence revenue use, and desire for re-election (in the case of our elected UC and DA members). Results are shown in columns 3-5.

We see that female DA members are less likely to have discussed revenue use; there is no strong gender effect among UC members or traditional authorities, likely because we have

${ }^{26}$ The coefficient are significant at $0.06<\mathrm{p}<0.14$ level in the OLS estimations (Table SA4, Columns 1-5) and at $0.06<\mathrm{p}<0.10$ in ordered logistic estimations (Table SA9, Columns 1-5).

${ }^{27}$ Note that due to a high correlation of $86 \%$ of the three personal rights measures, we only include two - the right to benefit from and the right to demand better handling of resource revenues - in our estimations. Results including the right to demand more information were very similar and are available upon request. 


\begin{tabular}{|c|c|c|c|c|c|}
\hline & \multicolumn{2}{|c|}{$\begin{array}{l}\text { Individual behavior, full } \\
\text { sample }\end{array}$} & \multicolumn{3}{|c|}{ Leader behavior } \\
\hline & $\begin{array}{l}\text { Discussed } \\
\text { use of } \\
\text { resource } \\
\text { revenues in } \\
\text { past } 12 \\
\text { months } \\
(1)\end{array}$ & $\begin{array}{c}\text { Contacted } \\
\text { someone in } \\
\text { past } 12 \\
\text { months } \\
\text { about } \\
\text { handling of } \\
\text { revenues } \\
(2)\end{array}$ & $\begin{array}{c}\text { UC } \\
\text { member } \\
\text { discussed } \\
\text { revenue } \\
\text { use with } \\
\text { peers in } \\
\text { past } 12 \\
\text { months } \\
\text { (3) }\end{array}$ & $\begin{array}{c}\text { DA } \\
\text { member } \\
\text { discussed } \\
\text { revenue } \\
\text { use with } \\
\text { peers in } \\
\text { past } 12 \\
\text { months } \\
(4)\end{array}$ & $\begin{array}{c}\text { Traditional } \\
\text { leader } \\
\text { discussed } \\
\text { revenue } \\
\text { use with } \\
\text { peers in } \\
\text { past } 12 \\
\text { months } \\
(5)\end{array}$ \\
\hline Female & + & + & - & $-* * *$ & - \\
\hline Urban district & + & + & $+^{*}$ & - & + \\
\hline Education level & $+* * *$ & $+^{*}$ & $-*$ & $+* * *$ & - \\
\hline Oil or mining nearby & $+* * *$ & $+* * *$ & $++* * *$ & $+++* * *$ & + \\
\hline Radio ownership & $+* * *$ & - & + & + & + \\
\hline TV ownership & - & + & - & - & $++* *$ \\
\hline Mobile phone ownership & + & - & $++* * *$ & $+* *$ & + \\
\hline Political interest & $+* * *$ & $+* *$ & $+*$ & + & $-* * *$ \\
\hline District Assembly member & $++* * *$ & $+* * *$ & & & \\
\hline Unit Committee member & $+* * *$ & $+* * *$ & & & \\
\hline Traditional leader & $++* * *$ & $+* * *$ & & & \\
\hline $\begin{array}{l}\text { Opinion leader } \\
\text { Received information on }\end{array}$ & $+* *$ & $+* * *$ & & & \\
\hline revenue management & $++* * *$ & $+* * *$ & + & $+* * *$ & + \\
\hline $\begin{array}{l}\text { Knowledge of institutions } \\
\text { (dummy) }\end{array}$ & $+* * *$ & $+* *$ & $-* * *$ & - & + \\
\hline $\begin{array}{l}\text { Knowledge of revenue } \\
\text { management }\end{array}$ & $++* * *$ & $+* * *$ & $+* * *$ & - & $+++* *$ \\
\hline $\begin{array}{l}\text { Local leaders right to a share } \\
\text { of revenues }\end{array}$ & $+* *$ & $+*$ & $+* * *$ & $+* * *$ & $+^{*}$ \\
\hline $\begin{array}{l}\text { Own right to benefit from } \\
\text { revenues }\end{array}$ & + & + & $+* *$ & - & $+++* *$ \\
\hline $\begin{array}{l}\text { Own right to demand better } \\
\text { handling of revenues }\end{array}$ & - & + & + & - & - \\
\hline Satisfaction with government & - & + & $+*$ & $+* * *$ & + \\
\hline Not my responsibility & $+* *$ & - & + & $+* * *$ & - \\
\hline Afraid of potential reprisals & $-* *$ & - & $+* * *$ & - & + \\
\hline No use & $-* * *$ & - & $-* * *$ & $-* * *$ & - \\
\hline
\end{tabular}

Notes: Overview of results of OLS estimations, including regional dummies and a constant term (not shown).

Table shows coefficient signs and levels of significance. One +/- denotes (absolute) coefficient magnitude from zero to 0.099; two +/- a coefficient magnitude from 0.1-0.199; three -/+ a coefficient magnitude from 0.2 upwards. $* * * p<0.01, * * p<0.05, * p<0.1$. Detailed results can be found in Appendix Tables A5-A6. 
very few female respondents. ${ }^{28}$ Curiously, the more educated UC members are the less likely, and the more educated DA members more likely, to have talked about revenue use. We have no ready explanation for this result. ${ }^{29}$ Having oil or mining activities nearby is linked to more frequent discussions with peers for UC and DA members, but less so for the chiefs. A general interest in politics is positively associated with discussion with peers for UC members', but there is a significant negative relation to chiefs' likelihood of discussing resource revenues.

Mobile phone ownership has a strong positive relation with the likelihood of discussing revenues with peers for UC and DA members, but this result is driven by the fact that none of the very few DA (1) and UC (8) members without mobile phones discussed the revenues with peers (which is why these variables are dropped in the logit estimations, see Table SA10, columns 1-6).

We find that knowledge levels about the resource sector and revenue use have conflicting effects on UC representatives' behavior, while information and knowledge of revenue management are positively linked to and DA members and chiefs' behaviour. ${ }^{30}$ Satisfaction with the government is linked to more frequent discussions for UC and DA members. The conclusion seems to be that more information and better knowledge can both stimulate discussion, but also reduce the frequency of discussions, perhaps because of a sense of already having the necessary information and not seeing any way of using this information in the political debate. Overall, we get a picture of positive links in the full sample between behaviour, and greater information and better knowledge about revenues and their use.

\subsection{Summary of results}

In sum, we confirm several findings from similar studies and find that information reception, subjective knowledge levels, attitudes and behavior depend very much on education levels and respondents' social leadership status, as well as on ownership of information media and general interest in political issues. Personal experience with resource extraction, measured by the proximity to extractive activities, also increases information dissemination and knowledge levels; and it tends to decrease satisfaction with the handling of resource revenues, and lead to more discussion and active demand for accountability in our overall sample and among elected leaders. There are some gender differences, with women appearing less knowledgeable about

\footnotetext{
${ }^{28}$ Our sample includes 67 female UC members, 35 female DA members and 12 female chiefs. None of the female DA members had discussed the revenue use in their DA meetings; this variable thus is dropped in the logistic estimations (Table SA10, Columns 4-6).

29 The logit results for UC members are weaker.

${ }^{30}$ The negative association for UC members is not significant in the logistic regression (Table SA10, Column 2).
} 
what is going on in the resource sector or, more likely, less (more) prone to exaggerating (understating) their knowledge. Women are also on average more satisfied with the current handling of revenues.

More importantly for the purpose of our study, we find that what information has reached citizens can be linked to some differences in attitudes and behavior with regards to resource revenue management. While greater knowledge of the relevant institutions and revenue flows has significant but contradictory links with rights perceptions (and is not linked to satisfaction levels), we get a clear picture of (small) positive relations with behavior of greater information and better knowledge about revenues and their use in the full sample. However, the link with leaders' behavior is more uncertain: information and knowledge levels affect elected representatives in both directions, while they have no discernible impact on traditional authorities, who instead seem mainly motivated by personal (monetary) interests.

Finally, our results on low demand for accountability are consistent with findings on citizens' demand for accountability emerging from other studies on citizens' behavior in Ghana. For example, the Seventh Round of the Afrobarometer Survey revealed that an overwhelming majority of Ghanaians do not engage with their elected and non-elected leaders: an average of $76 \%$ of the citizenry surveyed indicated that they had never contacted any of their formal or informal leaders to demand accountability during the year preceding the survey. With specific reference to elected officials, $71 \%$ and $84 \%$ of respondents respectively said they had never contacted their local councillors (assembly members) or Members of Parliament over the 12 months preceding the survey, while $87 \%$ indicated that they had not contacted a government official over the same period (Duayeden and Armah-Attoh 2018).

\section{Concluding remarks}

Our analysis offers a first detailed picture of Ghanaians' current state of knowledge on the use of Ghana's resource revenues, and how knowledge levels are related to attitudes towards and demand for accountability regarding resource revenue management. This is particularly important given what are perceived to be model rules for transparency and accountability surrounding petroleum revenues in Ghana, which were introduced in 2011.

Based on a unique survey dataset of over 3500 Ghanaians, gathered in 2016, we conclude that information dissemination on resource revenues and how they are used has not been able to reach much of the population, and that even many duty bearers are poorly informed. This runs counter to one of the main mechanisms proposed by the transparency literature: the availability of information is in fact not linked to widespread high levels of knowledge of the 
issues. Knowledge levels about revenue use are also not systematically linked to attitudes towards current resource policy. It is difficult to judge to what extent the overall low satisfaction levels with the current situation are affected by Ghanaians' often negative experience with the management of mining revenues; differences in the responses for mining and petroleum revenues were negligible, suggesting that respondents either do not distinguish the categories, or are genuinely dissatisfied with the handling of all resource revenues. Given the one-off nature of our dataset, we also don't have comparable data prior to the implementation of the PRMA and GHEITI, which means that we cannot draw any conclusions on the causal impacts of transparency measures in Ghana.

However, a more positive finding from our survey is that respondents with higher knowledge levels have on average more frequently discussed revenue-related issues with family, friends, or colleagues; and they are more likely to have approached someone to get more information on the use of revenues. This higher willingness to enter into debate and demand more accountability does lend some support to these steps in the transparency narrative.

In the context of Ghana's transparency policy, we could say that these mixed results imply that there is room for improvement both in disseminating information relating to resource revenue use, and in encouraging citizens to voice their concerns. However, perhaps the transparency discourse itself is too ambitious and optimistic in its assumptions. Rather than call for greater efforts in creating transparency for all, with the idea that this will quasiautomatically lead to greater awareness and demand for accountable use of resources, it is time to consider targeting those groups in society most likely to act as effective intermediaries between citizens and duty bearers, for example civil society and non-governmental organizations. Such a policy could complement the current general transparency efforts through information publication on the Internet and major newspapers.

\section{References}

1. Aaronson, S. A. (2011). Limited partnership: Business, government, civil society, and the public in the Extractive Industries Transparency Initiative (EITI). Public Administration and Development 31(1): 50-63. https://doi.org/10.1002/pad.588

2. Adusei, L. A.(2018). "Why Norway benefited from its oil and Ghana has not benefited from its gold", Article published in Business and Financial Times, January 9, 2018. 
3. Armand, A., Costa, A. I., Coutts, A., Vicente, P., and Vilela, I. (2018). On the mechanics of the political resource curse: Behavioral measurements of information and local elite behaviour in Mozambique, Final Report (S-89330-MOZ-1), International Growth Centre, London.

4. Ayee, J., Søreide, T., Shukla, G. P. and Le, T. M. (2011). 'Political economy of the mining sector in Ghana', Policy Research Working Paper 5730. Washington DC: The World Bank.

5. Bellver, A. and D. Kaufmann (2005). Transparenting transparency: initial empirics and policy applications. World Bank Policy Research Working Paper.

6. Buijze, A. (2013). The six faces of transparency. Utrecht Law Review 9(3): 3-25. DOI: http://doi.org/10.18352/ulr.233

7. Corrigan, C. C. (2014). Breaking the resource curse: Transparency in the natural resource sector and the Extractive Industries Transparency Initiative. Resources Policy 41: 17-30.

8. David-Barrett, E., \& Okamura, K. (2016). Norm diffusion and reputation: the rise of the Extractive Industries Transparency Initiative. Governance 29(2): 227-246.

9. Duayeden, K. A., \& Armah-Attoh, D. (2018). Afrobarometer Round 7 Survey in Ghana, 2017: Summary of results. Accra: CDD-Ghana.

10. Edjekumhene, I., D. Inkoom, C. K. Owusu (2018). Examining transparency and accountability within the oil and gas sector: Impact evaluation of key provisions in Ghana's Petroleum Revenue Management Act. KITE (Ghana), Final Process Evaluation Report TW8/1002.

11. EITI (2016). The EITI Standard 2016. Retrieved from Oslo: https://eiti.org/files/english_eiti_standard_0.pdf

12. Epremian, L., Lujala, P., \& Bruch, C. (2016). High-Value Natural Resources and Transparency: Accounting for Revenues and Governance. In Oxford Research Encyclopedia of Politics. DOI: 10.1093/acrefore/9780190228637.013.21

13. FES (Friedrich-Ebert-Stiftung) (2016). A Guide to District Assemblies in Ghana. FriedrichEbert-Stiftung Ghana and Institute of Local Government Studies.

14. Fiankor, D. K., \& Akussah, H. (2012). Information use and policy decision making by district assembly members in Ghana. Information Development 28(1): 32-42.

15. Florini, A. M. (2007). Introduction: The battle over transparency. In A. M. Florini (Ed.), The right to know: Transparency for an open world (pp. 1-18). New York: Columbia University Press.

16. Fox, J. (2015). Social Accountability: What Does the Evidence Really Say? World Development 72: 346-361. 
17. Gillies, A., \& Heuty, A. (2011). Does transparency work? The challenges of measurement and effectiveness in resource-rich countries. Yale Journal of International Affairs (SpringSummer): $25-42$.

18. Haufler, V. (2010). Disclosure as governance: The extractive industries transparency initiative and resource management in the developing world. Global Environmental Politics, 10 (3), 53-73

19. Heald, D. (2006). Transparency as an instrumental value. In C. Hood \& D. Heald (Eds.), Transparency: The key to better governance? Oxford: Oxford University Press.

20. Hirschman, A. O. (1970). Exit, voice and loyalty: Responses to decline in firms, organizations, and states. Cambridge (U.S.A.) and London (UK): Harvard University Press.

21. Hungerford, H. R., \& Volk, T. L. (1990). Changing learner behavior through environmental education. The Journal of Environmental Education 21(3): 8-21. http://dx.doi.org/10.1080/00958964.1990.10753743..

22. Joshi, A. (2013). Do They Work? Assessing the Impact of Transparency and Accountability Initiatives in Service Delivery. Development Policy Review 31 (S1): s29-s48. https://doi.org/10.1111/dpr.12018

23. Kasekende, E., Abuka, C., \& Sarr, M. (2016). Extractive industries and corruption: Investigating the effectiveness of EITI as scrutiny mechanism. Resources Policy 48: 117128.

24. Kolstad, I., \& Wiig, A. (2009). Is transparency the key to reducing corruption in resourcerich countries? World Development 37(3): 521-532.

25. Kollmuss A. \& J. Agyeman (2002). Mind the Gap: "Why do people act environmentally and what are the barriers to pro-environmental behavior?, Environmental Education Research 8(3): 239-260

26. Lujala, P., \& Epremian, L. (2017). Transparency and natural resource revenue management: Empowering the public with information? In A. Williams \& P. Le Billon (Eds.), Corruption, Natural Resources and Development, Cheltenham, UK: Edward Elgar Publishing.

27. Lujala, Päivi 2018. An analysis of the Extractive Industries Transparency Initiative implementation process. World Development 107(July): 358-381.

28. Lujala, P., Brunnschweiler, C., \& Edjekumhene, I. (2018). Transparent for whom? Dissemination of information on Ghana's petroleum and mining revenue management. MPRA working paper n. 84788. 
29. McDevitt, A. (2017). Transparency and Accountability in the Extractives Sector. K4D Helpdesk Report. Brighton, UK: Institute of Development Studies

30. Mejía Acosta, A. (2013). The impact and effectiveness of accountability and transparency initiatives: The governance of natural resources. Development Policy Review 31: 89-105.

31. Ministry of Finance, (2018). The Budget Statement and Economic Policy of Government of Ghana for 2018 Financial Year, Accra (Ghana).

32. Ofori, J. J. Y., \& Lujala, P. (2015). Illusionary Transparency? Oil Revenues, Information Disclosure, and Transparency. Society \& Natural Resources 28(11): 1187-1202. doi:10.1080/08941920.2015.1024806

33. Öge, K. (2014). The limits of transparency promotion in Azerbaijan: External remedies to "reverse the curse." Europe-Asia Studies 66: 1482-1500.

34. Rustad, Siri A., Philippe Le Billon and Päivi Lujala 2017. Has the Extractive Industries Transparency Initiative been a success? Identifying and evaluating EITI goals. Resources Policy 51(1): 151-162.

35. Scanteam (2011). Achievements and Strategic Options: Evaluation of the Extractive Industries Transparency Initiative. Final Report, Oslo.

36. Sovacool, B.K. and Andrews, N. (2015) Does Transparency Matter? Evaluating the Governance Impacts of the Extractive Industries Transparency Initiative (EITI) in Azerbaijan and Liberia. Resources Policy 45: 183-192.

37. Stiglitz, J. E. (2007). What is the role of the state? In M. Humphreys, J. D. Sachs, \& J. E. Stiglitz (Eds.), Escaping the resource curse, New York: Columbia University Press.

38. Van Alstine, J. (2014). Transparency in Resource Governance: The Pitfalls and Potential of "New Oil" in Sub-Saharan Africa. Global Environmental Politics 14(1): 20-39.

39. van der Ploeg, F. (2011). Natural Resources: Curse or Blessing? Journal of Economic Literature 49(2): 366-420. doi:10.1257/jel.49.2.366

40. World Bank (2003). 'Project performance assessment report, Ghana: Mining Sector Rehabilitation Project (Credit 1921-GH) and Mining Sector Development and Environment Project (Credit 2743-GH)'. Washington, DC: World Bank. 
Appendix Table A1. Summary statistics, survey questions and variable coding

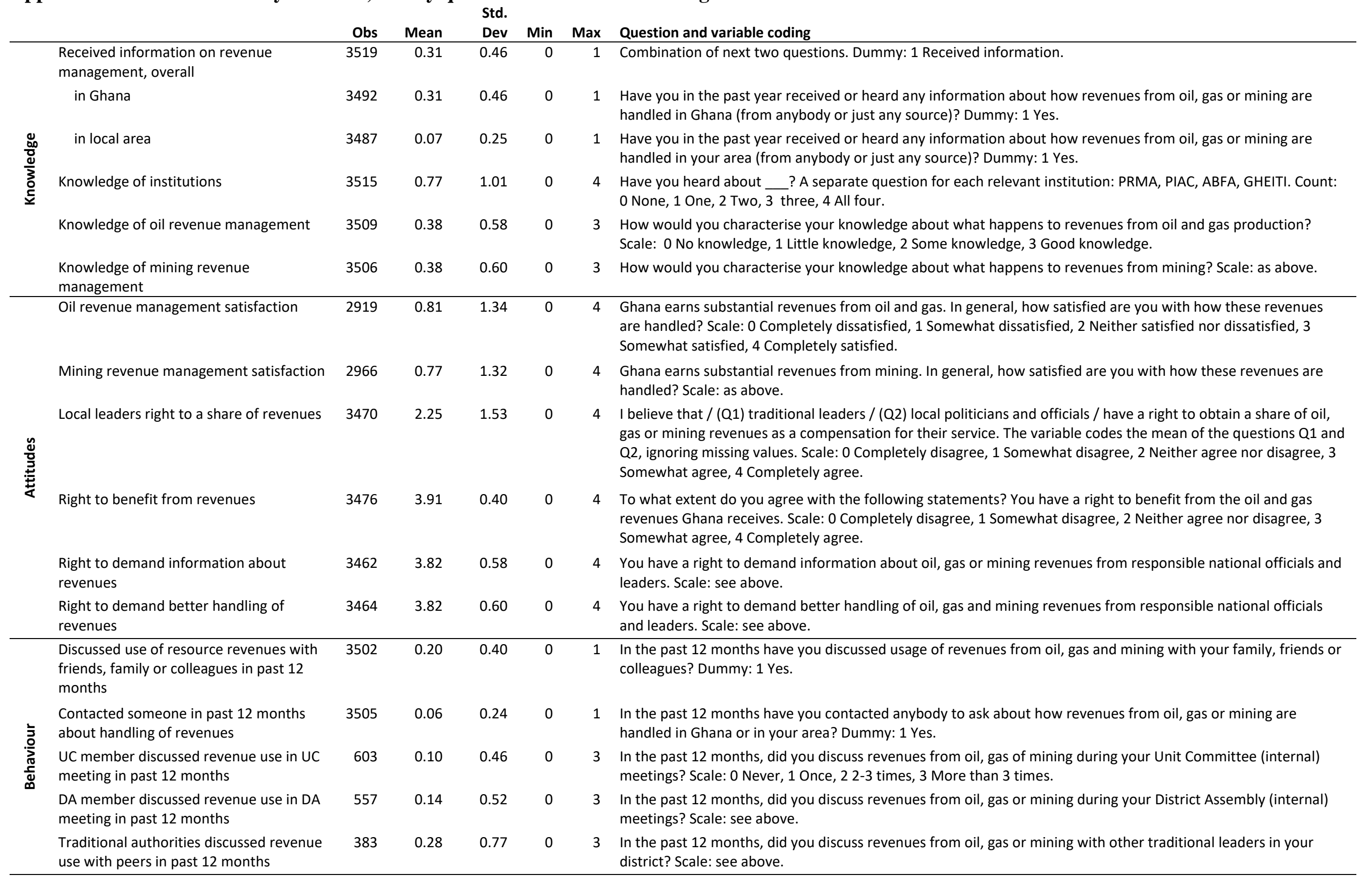


Female

Urban district

Education level

Oil or mining nearby

Radio ownership

TV ownership

Mobile phone ownership

Political interest

District Assembly membe

Unit Committee member

$\begin{array}{ll}\frac{y}{0} & \text { Traditional leader } \\ \frac{y}{0} & \text { Opinion leader } \\ \frac{0}{5} & \text { Knowledge of institutions (dummy) } \\ \frac{\lambda}{0} & \\ \frac{0}{0} & \text { Knowledge of revenue management } \\ \frac{\pi}{2} & \\ \frac{\pi}{x} & \end{array}$

Satisfaction with government

Not my responsibility

Afraid of potential reprisals

No use

1 Are you a male or female? Dummy: 1 Yes.

1 Is the area mostly rural or urban? Coded by the enumerator; 0 Mainly rural, 1 Mainly urban

8 What is your highest level of education? Scale from 0 None to 8 Completed tertiary.

1 To your knowledge, does any mining or oil company operate in or nearby your area? Dummy: 1 Yes.

1 Do you or a household member have radio? Dummy: 1 Yes.

1 Do you or a household member have television? Dummy: 1 Yes.

1 Do you or a household member have mobile phone? Dummy: 1 Yes.

5 How often do you discuss political matters and public affairs with friends, family or colleagues? Scale: 0 Never, 1 Rarely, 2 Sometimes, 3 Often, 4 Very often, 5 All the time.

1 Coded by the enumerator. Dummy: 1 Yes.

1 Coded by the enumerator. Dummy: 1 Yes.

1 Coded by the enumerator. Dummy: 1 Yes.

1 Coded by the enumerator. Dummy: 1 Yes.

1 Have you heard about __ ? A separate question for each relevant institution: PRMA, PIAC, ABFA, GHEITI. Dummy: 1 Had heard of at least one.

3 How would you characterise your knowledge about what happens to revenues from / oil and gas production / mining? The variable codes the mean of the two variables, ignoring missing values. Scale: 0 No knowledge, 1 Little knowledge, 2 Some knowledge, 3 Good knowledge.

4 To what extent do you agree with the following statements: Current government is doing a very good job in / improving the living standards of the poor / keeping prices down / creating jobs. The variable codes the mean of the three variables, ignoring missing values. When response to all three questions are missing, the variable is set to missing. Scale: 0 Completely disagree, 1 Somewhat disagree, 2 Neither agree nor disagree, 3 Somewhat agree, 4 Completely agree.

4 It is not my responsibility to improve the way revenues from oil, gas and mining are handled. Scale: see above.

4 I am afraid of potential reprisals if I tried to challenge the way how revenues from oil, gas and mining are handled. Scale: see above.

4 Even if I tried to get information about oil, gas or mining revenues from people above me, I would not receive any. Scale: see above. 


\section{Supplementary Appendix Table SA1. Knowledge of resource revenues and institutions}

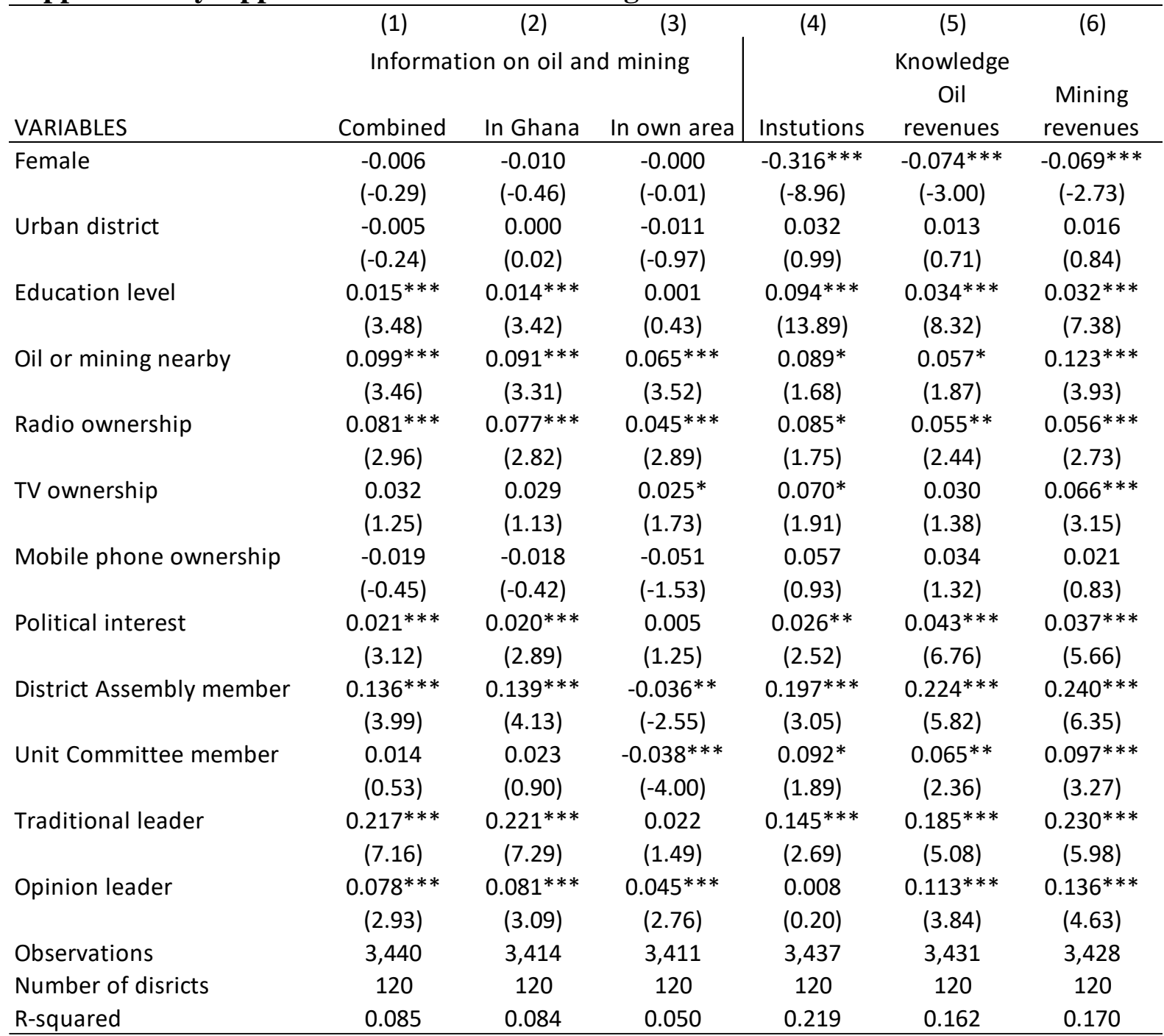

Notes: Table shows coefficients for OLS regressions. All specifications include regional dummies and a constant term (not shown). S.e. are clustered at the district and electoral area level. T-statistics in parentheses.

$* * * p<0.01, * * p<0.05, * p<0.1$. 


\section{Supplementary Appendix Table SA2. Satisfaction with resource revenue management}

\begin{tabular}{|c|c|c|c|c|c|c|}
\hline & (1) & $(2)$ & (3) & (4) & (5) & (6) \\
\hline VARIABLES & Oil & Oil & Oil & Mining & Mining & Mining \\
\hline \multirow[t]{2}{*}{ Female } & 0.075 & 0.055 & $0.198 * * *$ & 0.098 & 0.087 & $0.230 * * *$ \\
\hline & $(0.91)$ & $(0.66)$ & $(2.74)$ & $(1.25)$ & $(1.08)$ & $(3.36)$ \\
\hline \multirow[t]{2}{*}{ Urban district } & -0.029 & -0.026 & -0.011 & 0.003 & 0.004 & 0.029 \\
\hline & $(-0.44)$ & $(-0.39)$ & $(-0.18)$ & $(0.05)$ & $(0.06)$ & $(0.49)$ \\
\hline \multirow[t]{2}{*}{ Education level } & 0.024 & 0.022 & 0.014 & 0.005 & 0.004 & -0.001 \\
\hline & $(1.66)$ & $(1.40)$ & (1.08) & $(0.42)$ & $(0.31)$ & $(-0.11)$ \\
\hline \multirow{2}{*}{ Oil or mining nearby } & $-0.147 * *$ & $-0.180 * *$ & $-0.129 *$ & $-0.167^{* *}$ & $-0.184 * *$ & $-0.148^{* *}$ \\
\hline & $(-1.99)$ & $(-2.45)$ & $(-1.82)$ & $(-2.40)$ & $(-2.57)$ & $(-2.19)$ \\
\hline \multirow[t]{2}{*}{ Radio ownership } & $-0.259 *$ & $-0.272 *$ & -0.204 & $-0.279 *$ & $-0.287^{*}$ & -0.228 \\
\hline & $(-1.68)$ & $(-1.76)$ & $(-1.34)$ & $(-1.75)$ & $(-1.81)$ & $(-1.42)$ \\
\hline \multirow[t]{2}{*}{ TV ownership } & -0.148 & $-0.151^{*}$ & -0.036 & -0.128 & -0.131 & -0.029 \\
\hline & $(-1.65)$ & $(-1.69)$ & $(-0.45)$ & $(-1.40)$ & $(-1.44)$ & $(-0.34)$ \\
\hline \multirow[t]{2}{*}{ Mobile phone ownership } & $-0.339 *$ & $-0.340 *$ & -0.215 & 0.010 & 0.013 & 0.122 \\
\hline & $(-1.79)$ & $(-1.81)$ & $(-1.08)$ & $(0.06)$ & $(0.07)$ & $(0.58)$ \\
\hline \multirow[t]{2}{*}{ Political interest } & $-0.087^{* * *}$ & $-0.091 * * *$ & $-0.041 * *$ & $-0.083 * * *$ & $-0.088^{* * *}$ & $-0.041 * *$ \\
\hline & $(-3.79)$ & $(-4.00)$ & $(-2.01)$ & $(-3.91)$ & $(-4.15)$ & $(-2.16)$ \\
\hline \multirow[t]{2}{*}{ District Assembly member } & 0.144 & 0.119 & -0.049 & $0.207^{* *}$ & $0.179 *$ & 0.026 \\
\hline & $(1.57)$ & $(1.27)$ & $(-0.63)$ & $(2.28)$ & $(1.92)$ & $(0.34)$ \\
\hline \multirow[t]{2}{*}{ Unit Committee member } & $0.248 * * *$ & $0.245^{* *}$ & 0.122 & $0.275^{* * *}$ & $0.269 * * *$ & 0.124 \\
\hline & $(2.64)$ & $(2.61)$ & $(1.40)$ & $(3.01)$ & $(2.94)$ & $(1.42)$ \\
\hline \multirow[t]{2}{*}{ Traditional leader } & -0.093 & -0.138 & -0.076 & -0.022 & -0.063 & 0.002 \\
\hline & $(-0.93)$ & $(-1.35)$ & $(-0.83)$ & $(-0.23)$ & $(-0.63)$ & $(0.02)$ \\
\hline \multirow[t]{2}{*}{ Opinion leader } & $0.325^{* * *}$ & $0.305^{* * *}$ & $0.189 * *$ & $0.321 * * *$ & $0.299 * * *$ & $0.204^{* *}$ \\
\hline & $(3.40)$ & (3.14) & $(2.28)$ & $(3.41)$ & $(3.14)$ & $(2.53)$ \\
\hline \multirow{2}{*}{$\begin{array}{l}\text { Received information on revenue } \\
\text { management }\end{array}$} & & 0.113 & & & 0.094 & \\
\hline & & $(1.30)$ & & & $(1.17)$ & \\
\hline \multirow[t]{2}{*}{ Knowledge of institutions (dummy) } & & -0.091 & & & -0.082 & \\
\hline & & $(-1.22)$ & & & $(-1.15)$ & \\
\hline \multirow[t]{2}{*}{ Knowledge of revenue management } & & 0.088 & & & 0.091 & \\
\hline & & $(1.15)$ & & & $(1.26)$ & \\
\hline \multirow[t]{2}{*}{ Satisfaction with government } & & & $0.506 * * *$ & & & $0.468 * * *$ \\
\hline & & & $(17.43)$ & & & $(16.06)$ \\
\hline Observations & 2,869 & 2,864 & 2,779 & 2,910 & 2,905 & 2,818 \\
\hline Number of disricts & 120 & 120 & 120 & 120 & 120 & 120 \\
\hline R-squared & 0.108 & 0.112 & 0.310 & 0.103 & 0.106 & 0.289 \\
\hline
\end{tabular}

Notes: Table shows coefficients for OLS regressions. All specifications include regional dummies and a constant term (not shown). S.e. are clustered at the district and electoral area level. T-statistics in parentheses.

$* * * p<0.01, * * p<0.05, * p<0.1$. 


\section{Supplementary Appendix Table SA3. Rights perception}

\begin{tabular}{|c|c|c|c|c|c|c|c|c|c|c|c|c|}
\hline \multirow{2}{*}{ VARIABLES } & \multirow{2}{*}{\multicolumn{3}{|c|}{$\begin{array}{l}(1) \\
\text { Local leaders right to revenues }\end{array}$}} & (4) & (5) & (6) & (7) & (8) & (9) & (10) & (11) & (12) \\
\hline & & & & \multicolumn{3}{|c|}{ Own right to benefits } & \multicolumn{3}{|c|}{ Right to demand information } & \multicolumn{3}{|c|}{ Right to demand better handling } \\
\hline \multirow[t]{2}{*}{ Female } & -0.048 & 0.009 & -0.028 & -0.006 & -0.009 & 0.002 & $-0.128 * * *$ & $-0.118 * * *$ & $-0.101 * * *$ & $-0.122 * * *$ & $-0.114 * * *$ & $-0.100 * * *$ \\
\hline & $(-0.59)$ & $(0.11)$ & $(-0.34)$ & $(-0.24)$ & $(-0.37)$ & $(0.09)$ & $(-3.81)$ & $(-3.58)$ & $(-3.05)$ & $(-3.72)$ & $(-3.60)$ & $(-3.07)$ \\
\hline \multirow[t]{2}{*}{ Urban district } & 0.076 & 0.069 & 0.072 & 0.012 & 0.012 & 0.011 & -0.036 & -0.039 & -0.030 & -0.024 & -0.026 & -0.021 \\
\hline & (1.05) & (0.94) & $(1.00)$ & $(0.50)$ & $(0.53)$ & $(0.44)$ & $(-0.93)$ & $(-0.99)$ & $(-0.83)$ & $(-0.60)$ & $(-0.65)$ & $(-0.55)$ \\
\hline \multirow[t]{2}{*}{ Education level } & $-0.044 * * *$ & $-0.059 * * *$ & $-0.039 * *$ & 0.006 & 0.007 & 0.006 & $0.029 * * *$ & $0.024 * * *$ & $0.024 * * *$ & $0.031 * * *$ & $0.028 * * *$ & $0.027 * * *$ \\
\hline & $(-2.96)$ & $(-3.67)$ & $(-2.59)$ & (1.46) & (1.59) & (1.54) & $(3.74)$ & (3.08) & $(3.43)$ & $(4.11)$ & (3.58) & $(4.02)$ \\
\hline \multirow[t]{2}{*}{ Oil or mining nearby } & 0.024 & 0.021 & -0.017 & $0.039 *$ & $0.042^{*}$ & $0.041^{*}$ & -0.011 & -0.009 & 0.029 & 0.007 & 0.013 & 0.050 \\
\hline & $(0.24)$ & $(0.21)$ & $(-0.16)$ & (1.67) & $(1.75)$ & $(1.70)$ & $(-0.18)$ & $(-0.15)$ & $(0.57)$ & $(0.11)$ & $(0.21)$ & $(0.90)$ \\
\hline \multirow[t]{2}{*}{ Radio ownership } & $0.327^{* *}$ & $0.314 * *$ & $0.339 * *$ & $-0.092 * * *$ & $-0.090 * * *$ & $-0.082 * *$ & $-0.168 * * *$ & $-0.168 * * *$ & $-0.116 * *$ & $-0.169 * * *$ & $-0.166 * *$ & $-0.123 * *$ \\
\hline & $(2.52)$ & $(2.44)$ & $(2.51)$ & $(-2.92)$ & $(-2.84)$ & $(-2.45)$ & $(-2.70)$ & $(-2.71)$ & $(-2.09)$ & $(-2.62)$ & $(-2.56)$ & $(-2.10)$ \\
\hline \multirow[t]{2}{*}{ TV ownership } & -0.075 & -0.087 & -0.045 & -0.013 & -0.011 & -0.005 & 0.029 & 0.028 & 0.003 & 0.024 & 0.025 & 0.006 \\
\hline & $(-0.80)$ & $(-0.93)$ & $(-0.48)$ & $(-0.39)$ & $(-0.34)$ & $(-0.15)$ & (0.53) & (0.51) & $(0.05)$ & $(0.44)$ & $(0.46)$ & $(0.12)$ \\
\hline \multirow[t]{2}{*}{ Mobile phone ownership } & -0.089 & -0.107 & -0.091 & 0.025 & 0.026 & 0.036 & 0.075 & 0.074 & 0.124 & 0.030 & 0.030 & 0.064 \\
\hline & $(-0.51)$ & $(-0.61)$ & $(-0.51)$ & $(0.37)$ & $(0.37)$ & $(0.49)$ & $(0.66)$ & $(0.65)$ & (1.09) & $(0.26)$ & $(0.26)$ & $(0.56)$ \\
\hline \multirow[t]{2}{*}{ Political interest } & $-0.092 * * *$ & $-0.095 * * *$ & $-0.078 * * *$ & 0.009 & 0.010 & $0.013 * *$ & 0.013 & 0.014 & 0.011 & $0.021^{*}$ & $0.024 * *$ & 0.016 \\
\hline & $(-3.57)$ & $(-3.63)$ & $(-3.03)$ & (1.39) & (1.55) & $(1.98)$ & (1.18) & $(1.24)$ & (1.05) & $(1.93)$ & $(2.14)$ & $(1.52)$ \\
\hline \multirow[t]{2}{*}{ District Assembly member } & 0.150 & 0.117 & 0.105 & $0.064^{* *}$ & $0.071 * * *$ & $0.047^{*}$ & $0.107 * * *$ & $0.113 * * *$ & $0.101 * * *$ & $0.096 * * *$ & $0.111 * * *$ & $0.095 * * *$ \\
\hline & $(1.23)$ & (0.99) & $(0.86)$ & $(2.62)$ & $(2.88)$ & $(1.94)$ & (3.21) & (3.27) & (3.11) & (3.01) & (3.33) & $(3.07)$ \\
\hline \multirow[t]{2}{*}{ Unit Committee member } & $0.578 * * *$ & $0.561 * * *$ & $0.503^{* * *}$ & 0.022 & 0.024 & 0.006 & $0.126 * * *$ & $0.126 * * *$ & $0.113 * * *$ & $0.133 * * *$ & $0.135 * * *$ & $0.120 * * *$ \\
\hline & $(5.72)$ & (5.58) & $(4.72)$ & $(0.90)$ & (0.99) & $(0.24)$ & $(4.29)$ & $(4.20)$ & (3.62) & $(4.52)$ & $(4.49)$ & $(3.75)$ \\
\hline \multirow[t]{2}{*}{ Traditional leader } & $0.688 * * *$ & $0.679 * * *$ & $0.687^{* * *}$ & $0.095 * * *$ & $0.102 * * *$ & $0.095 * * *$ & -0.001 & 0.003 & -0.015 & -0.009 & 0.006 & -0.021 \\
\hline & $(6.61)$ & $(6.34)$ & $(6.59)$ & $(4.95)$ & $(5.30)$ & $(4.95)$ & $(-0.03)$ & $(0.05)$ & $(-0.31)$ & $(-0.16)$ & $(0.11)$ & $(-0.38)$ \\
\hline \multirow[t]{2}{*}{ Opinion leader } & -0.013 & -0.015 & -0.037 & -0.007 & -0.004 & -0.015 & -0.014 & -0.003 & -0.036 & -0.010 & 0.005 & -0.029 \\
\hline & $(-0.13)$ & $(-0.16)$ & $(-0.37)$ & $(-0.31)$ & $(-0.19)$ & $(-0.66)$ & $(-0.37)$ & $(-0.08)$ & $(-1.00)$ & $(-0.28)$ & $(0.14)$ & $(-0.80)$ \\
\hline Received information on & & 0.048 & & & -0.019 & & & 0.038 & & & 0.009 & \\
\hline revenue management & & $(0.60)$ & & & $(-0.64)$ & & & (0.99) & & & $(0.22)$ & \\
\hline Knowledge of institutions & & $0.284^{* * *}$ & & & -0.011 & & & $0.094^{* * *}$ & & & $0.090 * * *$ & \\
\hline (dummy) & & $(3.63)$ & & & $(-0.41)$ & & & $(2.93)$ & & & $(2.89)$ & \\
\hline Knowledge of revenue & & -0.012 & & & -0.017 & & & $-0.075^{* *}$ & & & $-0.095^{* * *}$ & \\
\hline management & & $(-0.16)$ & & & $(-0.63)$ & & & $(-2.23)$ & & & $(-2.91)$ & \\
\hline Satisfaction with & & & $0.060 * *$ & & & $0.032 * * *$ & & & 0.017 & & & 0.012 \\
\hline government & & & $(2.20)$ & & & $(4.91)$ & & & (1.32) & & & $(0.85)$ \\
\hline Observations & 3,394 & 3,384 & 3,259 & 3,400 & 3,390 & 3,263 & 3,388 & 3,378 & 3,251 & 3,390 & 3,380 & 3,253 \\
\hline Number of disricts & 120 & 120 & 120 & 120 & 120 & 120 & 120 & 120 & 120 & 120 & 120 & 120 \\
\hline R-squared & 0.082 & 0.088 & 0.085 & 0.061 & 0.062 & 0.070 & 0.094 & 0.098 & 0.086 & 0.089 & 0.093 & 0.081 \\
\hline
\end{tabular}

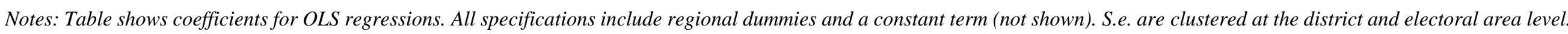

T-statistics in parentheses. $* * * p<0.01$, ** $p<0.05, * p<0.1$. 


\section{Supplementary Appendix Table SA4. Individual behavior, full sample}

\begin{tabular}{|c|c|c|c|c|c|c|c|c|c|c|}
\hline \multirow[b]{2}{*}{ VARIABLES } & (1) & $(2)$ & (3) & (4) & (5) & (6) & (7) & (8) & (9) & (10) \\
\hline & \multicolumn{5}{|c|}{ Discussed use of resource revenues in past 12 months } & \multicolumn{5}{|c|}{ Contacted someone in past 12 months about handling of revenues } \\
\hline \multirow[t]{2}{*}{ Female } & 0.019 & $0.044^{* *}$ & 0.015 & 0.017 & 0.007 & 0.005 & 0.011 & 0.006 & 0.005 & 0.005 \\
\hline & $(1.07)$ & $(2.52)$ & $(0.84)$ & $(0.97)$ & $(0.39)$ & $(0.52)$ & $(1.18)$ & $(0.62)$ & (0.49) & $(0.49)$ \\
\hline \multirow[t]{2}{*}{ Urban district } & 0.026 & 0.024 & 0.026 & 0.025 & $0.032^{*}$ & 0.003 & 0.003 & 0.004 & 0.001 & 0.004 \\
\hline & $(1.62)$ & (1.61) & (1.59) & $(1.50)$ & $(1.97)$ & $(0.44)$ & $(0.45)$ & $(0.51)$ & $(0.12)$ & $(0.46)$ \\
\hline \multirow[t]{2}{*}{ Education level } & $0.009 * * *$ & -0.003 & $0.010 * * *$ & $0.008^{* *}$ & $0.009 * * *$ & $0.005^{* *}$ & 0.001 & $0.005^{* *}$ & $0.004^{*}$ & $0.004^{*}$ \\
\hline & $(2.91)$ & $(-0.95)$ & (3.22) & $(2.52)$ & (2.91) & $(2.06)$ & $(0.39)$ & $(2.04)$ & (1.79) & $(1.92)$ \\
\hline \multirow[t]{2}{*}{ Oil or mining nearby } & $0.072^{* * *}$ & 0.034 & $0.073^{* * *}$ & $0.070 * * *$ & $0.082 * * *$ & $0.054 * * *$ & $0.038 * * *$ & $0.057^{* * *}$ & $0.056 * * *$ & $0.057^{* * *}$ \\
\hline & $(2.94)$ & $(1.62)$ & $(2.96)$ & $(2.86)$ & (3.32) & (3.88) & $(3.24)$ & (3.89) & (3.91) & $(4.02)$ \\
\hline \multirow[t]{2}{*}{ Radio ownership } & $0.057^{* * *}$ & $0.032 *$ & $0.053^{* * *}$ & $0.066^{* * *}$ & $0.065^{* * *}$ & -0.005 & -0.013 & -0.006 & 0.003 & -0.004 \\
\hline & (3.14) & $(1.88)$ & $(2.78)$ & (3.59) & (3.19) & $(-0.40)$ & $(-1.06)$ & $(-0.42)$ & $(0.27)$ & $(-0.29)$ \\
\hline \multirow[t]{2}{*}{ TV ownership } & -0.002 & -0.018 & -0.003 & -0.009 & -0.013 & 0.009 & 0.004 & 0.008 & 0.007 & 0.008 \\
\hline & $(-0.12)$ & $(-0.91)$ & $(-0.13)$ & $(-0.43)$ & $(-0.60)$ & (1.13) & $(0.56)$ & $(0.95)$ & $(0.82)$ & $(0.88)$ \\
\hline \multirow[t]{2}{*}{ Mobile phone ownership } & 0.017 & 0.011 & 0.011 & 0.019 & 0.012 & -0.016 & -0.019 & -0.020 & -0.018 & -0.018 \\
\hline & $(0.57)$ & $(0.39)$ & $(0.33)$ & $(0.58)$ & $(0.38)$ & $(-0.81)$ & $(-0.93)$ & $(-0.87)$ & $(-0.81)$ & $(-0.84)$ \\
\hline \multirow[t]{2}{*}{ Political interest } & $0.021^{* * *}$ & $0.012^{* *}$ & $0.021 * * *$ & $0.022 * * *$ & $0.025^{* * *}$ & $0.006^{* *}$ & 0.004 & $0.007^{* *}$ & $0.006^{* *}$ & $0.006^{* *}$ \\
\hline & (3.65) & $(2.17)$ & (3.57) & (3.65) & (4.21) & $(2.16)$ & $(1.28)$ & $(2.23)$ & $(2.25)$ & $(2.09)$ \\
\hline \multirow[t]{2}{*}{ District Assembly member } & $0.116^{* * *}$ & $0.054^{*}$ & $0.116^{* * *}$ & $0.121 * * *$ & $0.117^{* * *}$ & $0.081^{* * *}$ & $0.061 * * *$ & $0.080 * * *$ & $0.081^{* * *}$ & $0.081^{* * *}$ \\
\hline & $(4.25)$ & $(1.98)$ & $(4.21)$ & $(4.38)$ & $(4.27)$ & $(5.12)$ & $(3.86)$ & $(5.05)$ & $(5.07)$ & $(5.05)$ \\
\hline \multirow[t]{2}{*}{ Unit Committee member } & $0.098 * * *$ & $0.081^{* * *}$ & $0.101^{* * *}$ & $0.089 * * *$ & $0.102 * * *$ & $0.054 * * *$ & $0.048^{* * *}$ & $0.053^{* * *}$ & $0.050 * * *$ & $0.060 * * *$ \\
\hline & (4.54) & $(4.08)$ & $(4.45)$ & (3.91) & $(4.61)$ & $(4.31)$ & (3.91) & $(4.08)$ & (3.88) & $(4.47)$ \\
\hline \multirow[t]{2}{*}{ Traditional leader } & $0.158 * * *$ & $0.094 * * *$ & $0.155^{* * *}$ & $0.155^{* * *}$ & $0.132 * * *$ & $0.061^{* * *}$ & $0.041 * * *$ & $0.060 * * *$ & $0.062^{* * *}$ & $0.060 * * *$ \\
\hline & (6.39) & $(4.00)$ & $(6.00)$ & $(6.22)$ & $(5.12)$ & $(4.77)$ & $(3.49)$ & $(4.47)$ & (4.75) & $(4.56)$ \\
\hline \multirow[t]{2}{*}{ Opinion leader } & $0.039 * *$ & 0.010 & $0.041 * *$ & $0.037^{* *}$ & $0.036^{*}$ & $0.046^{* * *}$ & $0.037^{* * *}$ & $0.047^{* * *}$ & $0.044^{* * *}$ & $0.048 * * *$ \\
\hline & $(2.16)$ & $(0.65)$ & $(2.24)$ & $(2.04)$ & $(1.91)$ & $(3.58)$ & $(3.16)$ & (3.57) & $(3.39)$ & $(3.54)$ \\
\hline Received information on & & $0.158 * * *$ & & & & & $0.033^{* * *}$ & & & \\
\hline revenue management & & $(6.77)$ & & & & & $(3.25)$ & & & \\
\hline Knowledge of institutions & & $0.080 * * *$ & & & & & $0.018^{* *}$ & & & \\
\hline (dummy) & & $(4.27)$ & & & & & $(2.39)$ & & & \\
\hline Knowledge of revenue & & $0.141^{* * *}$ & & & & & $0.061^{* * *}$ & & & \\
\hline management & & $(6.92)$ & & & & & $(5.30)$ & & & \\
\hline Local leaders right to a share & & & $0.011^{* *}$ & & & & & $0.004^{*}$ & & \\
\hline of revenues & & & $(2.47)$ & & & & & $(1.67)$ & & \\
\hline Own right to benefit from & & & 0.016 & & & & & 0.002 & & \\
\hline revenues & & & $(1.27)$ & & & & & $(0.49)$ & & \\
\hline Own right to demand better & & & -0.010 & & & & & 0.003 & & \\
\hline handling of revenues & & & $(-0.94)$ & & & & & $(0.54)$ & & \\
\hline \multirow[t]{2}{*}{ Satisfaction with government } & & & & -0.001 & & & & & 0.003 & \\
\hline & & & & $(-0.22)$ & & & & & $(1.58)$ & \\
\hline \multirow[t]{2}{*}{ Not my responsibility } & & & & & $0.012^{* *}$ & & & & & -0.002 \\
\hline & & & & & $(2.25)$ & & & & & $(-0.86)$ \\
\hline \multirow[t]{2}{*}{ Afraid of potential reprisals } & & & & & $-0.012 * *$ & & & & & -0.004 \\
\hline & & & & & $(-2.42)$ & & & & & $(-1.37)$ \\
\hline \multirow[t]{2}{*}{ No use } & & & & & $-0.024 * * *$ & & & & & -0.002 \\
\hline & & & & & $(-4.83)$ & & & & & $(-0.90)$ \\
\hline Observations & 3,425 & 3,416 & 3,337 & 3,285 & 3,265 & 3,427 & 3,418 & 3,340 & 3,287 & 3,268 \\
\hline Number of disricts & 120 & 120 & 120 & 120 & 120 & 120 & 120 & 120 & 120 & 120 \\
\hline R-squared & 0.108 & 0.221 & 0.108 & 0.108 & 0.123 & 0.059 & 0.099 & 0.061 & 0.059 & 0.061 \\
\hline
\end{tabular}

Notes: Table shows coefficients for OLS regressions. All specifications include regional dummies and a constant term (not shown).

S.e. are clustered at the district and electoral area level. $T$-statistics in parentheses. $* * * p<0.01, * * p<0.05, * p<0.1$. 
Supplementary Appendix Table SA5. Leader behavior

\begin{tabular}{|c|c|c|c|c|c|c|c|c|c|c|c|c|c|c|c|}
\hline \multirow{3}{*}{$\begin{array}{l}\text { VARIABLES } \\
\text { Female }\end{array}$} & member & cussed $r$ & e use wi & ers in & months & DA membe & iscussed $r$ & ue use w & peers in $p$ & $\begin{array}{c}\text { (10) } \\
\text { t } 12 \text { months }\end{array}$ & $\begin{array}{l}(11) \\
\text { hief discus: }\end{array}$ & $\begin{array}{l}\text { (12) } \\
\text { sed revenu }\end{array}$ & $\begin{array}{l}\quad(13) \\
\text { e use with }\end{array}$ & $\begin{array}{l}\text { (14) } \\
\text { peers in pas }\end{array}$ & $\begin{array}{c}\text { (15) } \\
\text { it } 12 \text { month }\end{array}$ \\
\hline & -0.007 & -0.005 & 0.013 & 0.019 & -0.019 & $-0.088^{* * *}$ & $-0.088^{* * *}$ & $-0.089 * * *$ & $-0.091 * * *$ & $-0.101^{* * *}$ & -0.173 & -0.080 & -0.186 & -0.157 & -0.155 \\
\hline & $(-0.46)$ & $(-0.31)$ & $(0.99)$ & (1.05) & $(-1.27)$ & $(-6.31)$ & $(-6.65)$ & $(-6.61)$ & $(-6.07)$ & $(-7.32)$ & $(-1.40)$ & $(-0.70)$ & $(-1.51)$ & $(-1.28)$ & $(-1.19)$ \\
\hline \multirow[t]{2}{*}{ Urban district } & $0.032^{*}$ & 0.026 & 0.031 & 0.012 & $0.043^{* *}$ & -0.025 & -0.024 & -0.026 & -0.014 & -0.028 & 0.020 & 0.018 & 0.037 & 0.020 & 0.029 \\
\hline & (1.69) & $(1.47)$ & (1.61) & $(0.75)$ & (2.38) & $(-1.43)$ & $(-1.34)$ & $(-1.46)$ & $(-0.78)$ & $(-1.61)$ & $(0.30)$ & $(0.27)$ & $(0.52)$ & $(0.29)$ & $(0.43)$ \\
\hline \multirow[t]{2}{*}{ Education level } & $-0.012^{* *}$ & $-0.014^{* *}$ & $-0.012^{*}$ & -0.001 & $-0.012^{*}$ & $0.029 * * *$ & $0.028^{* * *}$ & $0.028 * * *$ & $0.030^{* * *}$ & $0.027^{* * *}$ & -0.018 & $-0.036 *$ & -0.017 & -0.015 & -0.023 \\
\hline & $(-2.06)$ & $(-2.34)$ & $(-1.95)$ & $(-0.21)$ & $(-1.87)$ & (5.42) & $(5.67)$ & (5.15) & (5.58) & (4.83) & $(-1.15)$ & $(-1.93)$ & $(-1.09)$ & $(-0.93)$ & $(-1.48)$ \\
\hline \multirow[t]{2}{*}{ Oil or mining nearby } & $0.116^{* * *}$ & $0.101^{* * *}$ & $0.112^{* * *}$ & $0.133^{* * *}$ & $0.113^{* * *}$ & $0.274^{* * *}$ & $0.262^{* * *}$ & $0.278^{* * *}$ & $0.266^{* * *}$ & $0.282^{* * *}$ & 0.164 & 0.102 & 0.168 & 0.183 & 0.193 \\
\hline & (8.92) & $(6.77)$ & (8.12) & $(7.66)$ & $(8.16)$ & $(10.50)$ & (9.93) & $(10.46)$ & (10.43) & (11.18) & $(1.23)$ & $(0.82)$ & (1.33) & $(1.37)$ & (1.43) \\
\hline \multirow[t]{2}{*}{ Radio ownership } & 0.009 & 0.008 & 0.001 & $-0.060^{* *}$ & 0.004 & 0.036 & 0.027 & 0.034 & 0.048 & 0.044 & 0.075 & 0.052 & 0.087 & 0.074 & 0.091 \\
\hline & $(0.35)$ & $(0.30)$ & $(0.04)$ & $(-2.50)$ & (0.14) & $(0.52)$ & $(0.42)$ & $(0.49)$ & $(0.73)$ & $(0.63)$ & $(0.65)$ & $(0.44)$ & $(0.70)$ & $(0.60)$ & $(0.71)$ \\
\hline \multirow[t]{2}{*}{ TV ownership } & -0.039 & -0.041 & -0.036 & 0.025 & -0.050 & -0.001 & -0.003 & 0.003 & -0.007 & 0.003 & $0.200^{* *}$ & $0.187^{* *}$ & $0.178^{*}$ & $0.202^{* *}$ & $0.197^{*}$ \\
\hline & $(-1.00)$ & $(-1.07)$ & $(-0.89)$ & $(0.88)$ & $(-1.27)$ & $(-0.05)$ & $(-0.08)$ & $(0.11)$ & $(-0.23)$ & $(0.10)$ & (2.02) & (2.03) & (1.79) & (2.03) & (1.84) \\
\hline \multirow[t]{2}{*}{ Mobile phone ownership } & $0.120^{* * *}$ & $0.107^{* * *}$ & $0.102^{* * *}$ & $0.110^{* * *}$ & $0.140^{* * *}$ & $0.094^{* *}$ & $0.082^{*}$ & $0.113^{* *}$ & $0.093^{*}$ & $0.097^{* *}$ & 0.088 & 0.059 & 0.103 & 0.082 & 0.070 \\
\hline & $(5.37)$ & $(4.26)$ & $(4.51)$ & (5.13) & $(5.65)$ & $(2.06)$ & (1.85) & (2.37) & (1.97) & (2.11) & $(0.70)$ & $(0.47)$ & $(0.83)$ & $(0.66)$ & $(0.51)$ \\
\hline \multirow[t]{2}{*}{ Political interest } & $0.012^{* *}$ & $0.010^{*}$ & $0.013^{* *}$ & 0.003 & 0.008 & 0.005 & 0.002 & 0.007 & 0.002 & 0.010 & $-0.047^{* * *}$ & $-0.061 * * *$ & $-0.047 * * *$ & $-0.048 * *$ & $-0.048 * *$ \\
\hline & (2.21) & (1.72) & (2.28) & $(0.91)$ & (1.49) & (0.59) & (0.32) & $(0.85)$ & (0.24) & (1.20) & $(-2.79)$ & $(-3.66)$ & $(-2.87)$ & $(-2.49)$ & $(-2.58)$ \\
\hline \multirow{2}{*}{$\begin{array}{l}\text { Received information on revenue } \\
\text { management }\end{array}$} & & 0.018 & & & & & $0.077^{* * *}$ & & & & & 0.027 & & & \\
\hline & & $(0.62)$ & & & & & $(4.04)$ & & & & & $(0.36)$ & & & \\
\hline \multirow[t]{2}{*}{ Knowledge of institutions (dummy) } & & $-0.045^{* * *}$ & & & & & -0.010 & & & & & 0.064 & & & \\
\hline & & $(-2.97)$ & & & & & $(-0.49)$ & & & & & $(0.62)$ & & & \\
\hline \multirow[t]{2}{*}{ Knowledge of revenue management } & & $0.092^{* * *}$ & & & & & -0.014 & & & & & $0.200^{* *}$ & & & \\
\hline & & $(3.90)$ & & & & & $(-0.71)$ & & & & & (2.05) & & & \\
\hline \multirow{2}{*}{$\begin{array}{l}\text { Local leaders right to a share of } \\
\text { revenues }\end{array}$} & & & $0.031^{* * *}$ & & & & & $0.025^{* * *}$ & & & & & $0.048^{*}$ & & \\
\hline & & & (5.88) & & & & & (3.77) & & & & & (1.70) & & \\
\hline \multirow[t]{2}{*}{ Own right to benefit from revenues } & & & $0.010^{* *}$ & & & & & -0.009 & & & & & $0.865^{* *}$ & & \\
\hline & & & (2.38) & & & & & $(-0.92)$ & & & & & (2.21) & & \\
\hline Own right to demand better & & & 0.000 & & & & & -0.020 & & & & & -0.014 & & \\
\hline handling of revenues & & & $(0.06)$ & & & & & $(-1.62)$ & & & & & $(-0.19)$ & & \\
\hline \multirow[t]{2}{*}{ Satisfaction with government } & & & & $0.013^{*}$ & & & & & $0.028^{* * *}$ & & & & & 0.008 & \\
\hline & & & & $(1.76)$ & & & & & $(3.99)$ & & & & & $(0.21)$ & \\
\hline \multirow[t]{2}{*}{ Not my responsibility } & & & & & 0.004 & & & & & $0.040^{* * *}$ & & & & & -0.014 \\
\hline & & & & & (0.65) & & & & & (6.11) & & & & & $(-0.58)$ \\
\hline \multirow[t]{2}{*}{ Afraid of potential reprisals } & & & & & $0.023^{* * *}$ & & & & & -0.005 & & & & & 0.010 \\
\hline & & & & & (3.58) & & & & & $(-1.02)$ & & & & & $(0.43)$ \\
\hline \multirow[t]{2}{*}{ No use } & & & & & $-0.019^{* * *}$ & & & & & $-0.019 * * *$ & & & & & -0.038 \\
\hline & & & & & $(-3.56)$ & & & & & $(-3.70)$ & & & & & $(-1.54)$ \\
\hline Observations & 593 & 592 & 577 & 520 & 566 & 556 & 556 & 550 & 551 & 544 & 375 & 374 & 364 & 365 & 362 \\
\hline Number of disricts & 0.036 & 0.048 & 0.044 & 0.035 & 0.047 & 0.130 & 0.134 & 0.137 & 0.137 & 0.140 & 0.214 & 0.239 & 0.218 & 0.224 & 0.227 \\
\hline R-squared & 120 & 120 & 120 & 110 & 120 & 113 & 113 & 113 & 113 & 113 & 102 & 102 & 101 & 102 & 100 \\
\hline
\end{tabular}

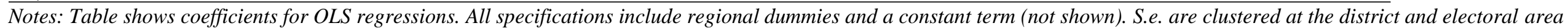
level. T-statistics in parentheses. $* * * p<0.01, * * p<0.05$, * $p<0.1$. 
Supplementary Appendix Table SA6. Knowledge of resource revenues and institutions, logistic and ordered logistic estimations of the models in SA1

\begin{tabular}{|c|c|c|c|c|c|c|}
\hline \multirow[b]{3}{*}{ VARIABLES } & (1) & $(2)$ & (3) & (4) & (5) & (6) \\
\hline & \multicolumn{3}{|c|}{ Information on oil and mining } & \multicolumn{3}{|c|}{ Knowledge } \\
\hline & Combined & In Ghana & In own area & Instutions & Oil revenues & revenues \\
\hline \multirow[t]{2}{*}{ Female } & 0.954 & 0.934 & 1.064 & $0.375^{* * *}$ & $0.611 * * *$ & $0.625 * * *$ \\
\hline & $(-0.39)$ & $(-0.57)$ & (0.29) & $(-8.95)$ & $(-3.43)$ & $(-3.15)$ \\
\hline \multirow[t]{2}{*}{ Urban district } & 0.983 & 1.011 & 0.809 & 1.102 & 1.067 & 1.117 \\
\hline & $(-0.16)$ & (0.10) & $(-1.09)$ & $(0.97)$ & $(0.58)$ & $(0.96)$ \\
\hline \multirow[t]{2}{*}{ Education level } & $1.087^{* * *}$ & $1.087^{* * *}$ & 1.013 & $1.360 * * *$ & $1.214^{* * *}$ & $1.204^{* * *}$ \\
\hline & $(3.40)$ & (3.36) & $(0.35)$ & (13.39) & (7.76) & $(6.93)$ \\
\hline \multirow[t]{2}{*}{ Oil or mining nearby } & $1.668 * * *$ & $1.618^{* * *}$ & $2.337 * * *$ & 1.203 & $1.293^{*}$ & $1.670 * * *$ \\
\hline & (3.58) & (3.41) & (3.91) & (1.34) & $(1.81)$ & (3.66) \\
\hline \multirow[t]{2}{*}{ Radio ownership } & $1.949 * * *$ & $1.940 * *$ & $2.672^{*}$ & 1.395 & $2.026 * *$ & $2.010 * *$ \\
\hline & $(2.67)$ & $(2.57)$ & (1.98) & (1.60) & $(2.41)$ & $(2.52)$ \\
\hline \multirow[t]{2}{*}{ TV ownership } & 1.231 & 1.213 & 1.562 & 1.245 & 1.238 & $1.630 * *$ \\
\hline & $(1.22)$ & (1.11) & (1.58) & (1.38) & (1.17) & $(2.61)$ \\
\hline \multirow[t]{2}{*}{ Mobile phone ownership } & 0.926 & 0.924 & $0.447^{*}$ & $2.308^{*}$ & $2.852^{*}$ & $2.400 *$ \\
\hline & $(-0.24)$ & $(-0.24)$ & $(-1.86)$ & (1.85) & (1.93) & $(1.71)$ \\
\hline \multirow[t]{2}{*}{ Political interest } & $1.112 * * *$ & $1.106 * *$ & 1.091 & 1.034 & $1.234 * * *$ & $1.196 * * *$ \\
\hline & $(2.84)$ & $(2.61)$ & (1.39) & (1.09) & $(6.47)$ & $(5.28)$ \\
\hline \multirow[t]{2}{*}{ District Assembly member } & $1.884^{* * *}$ & $1.931 * * *$ & $0.529 * *$ & $1.247^{*}$ & $1.988 * * *$ & $2.230 * * *$ \\
\hline & (3.84) & $(4.00)$ & $(-2.35)$ & $(1.71)$ & (4.57) & $(5.31)$ \\
\hline \multirow[t]{2}{*}{ Unit Committee member } & 1.109 & 1.177 & $0.359 * * *$ & $1.305^{* *}$ & $1.491 * * *$ & $1.784 * * *$ \\
\hline & (0.69) & (1.09) & $(-3.81)$ & (2.19) & $(2.80)$ & (3.84) \\
\hline \multirow[t]{2}{*}{ Traditional leader } & $2.986 * * *$ & $3.083 * * *$ & $1.601^{*}$ & $1.316^{*}$ & $2.485^{* * *}$ & $3.140 * * *$ \\
\hline & (7.31) & (7.47) & $(1.77)$ & $(1.87)$ & $(5.47)$ & $(6.56)$ \\
\hline \multirow[t]{2}{*}{ Opinion leader } & $1.517 * * *$ & $1.561^{* * *}$ & $1.851 * * *$ & 0.926 & $1.786 * * *$ & $2.095 * * *$ \\
\hline & $(2.92)$ & (3.11) & $(2.80)$ & $(-0.72)$ & (3.75) & $(4.76)$ \\
\hline Observations & 3,440 & 3,414 & 3,411 & 3,437 & 3,431 & 3,428 \\
\hline Number of disricts & 120 & 120 & 120 & 120 & 120 & 120 \\
\hline
\end{tabular}

Notes: Table shows odd ratios for logistic (columns 1-3) and ordered logistic regressions (columns 4-6). All specifications include regional dummies and columns 1-3 a constant term (not shown). S.e. are clustered at the district and electoral area level. T-statistics in parentheses. $* * * p<0.01, * * p<0.05, * p<0.1$. 
Supplementary Appendix Table SA7. Satisfaction with resource revenue management, ordered logistic estimations of the models in SA2

\begin{tabular}{|c|c|c|c|c|c|c|}
\hline & (1) & (2) & (3) & (4) & (5) & (6) \\
\hline VARIABLES & Oil & Oil & Oil & Mining & Mining & Mining \\
\hline \multirow{2}{*}{ Female } & 1.199 & 1.174 & $1.629 * * *$ & $1.326 * *$ & $1.303^{*}$ & $1.831 * * *$ \\
\hline & (1.29) & (1.10) & $(3.32)$ & (1.99) & $(1.80)$ & $(4.05)$ \\
\hline \multirow[t]{2}{*}{ Urban district } & 0.952 & 0.957 & 0.956 & 0.985 & 0.987 & 1.027 \\
\hline & $(-0.40)$ & $(-0.37)$ & $(-0.36)$ & $(-0.13)$ & $(-0.11)$ & $(0.21)$ \\
\hline \multirow[t]{2}{*}{ Education level } & $1.043^{*}$ & 1.041 & 1.029 & 1.002 & 1.000 & 0.988 \\
\hline & $(1.77)$ & $(1.50)$ & $(1.09)$ & $(0.09)$ & $(0.00)$ & $(-0.50)$ \\
\hline \multirow[t]{2}{*}{ Oil or mining nearby } & $0.711^{* *}$ & $0.673 * *$ & $0.671 * *$ & $0.708^{* *}$ & $0.677^{* *}$ & $0.673 * *$ \\
\hline & $(-2.11)$ & $(-2.41)$ & $(-2.23)$ & $(-2.32)$ & $(-2.56)$ & $(-2.28)$ \\
\hline \multirow[t]{2}{*}{ Radio ownership } & 0.710 & $0.696 *$ & 0.784 & $0.672 *$ & $0.663^{*}$ & 0.717 \\
\hline & $(-1.65)$ & $(-1.74)$ & $(-0.94)$ & $(-1.84)$ & $(-1.90)$ & $(-1.28)$ \\
\hline \multirow[t]{2}{*}{ TV ownership } & $0.784^{*}$ & $0.783^{*}$ & 0.907 & 0.838 & 0.836 & 1.016 \\
\hline & $(-1.71)$ & $(-1.71)$ & $(-0.62)$ & $(-1.17)$ & $(-1.19)$ & (0.09) \\
\hline \multirow[t]{2}{*}{ Mobile phone ownership } & $0.621 *$ & $0.622 *$ & 0.729 & 1.045 & 1.053 & 1.213 \\
\hline & $(-1.94)$ & $(-1.93)$ & $(-0.97)$ & $(0.16)$ & (0.19) & $(0.50)$ \\
\hline \multirow[t]{2}{*}{ Political interest } & $0.827 * * *$ & $0.822 * * *$ & $0.876 * * *$ & $0.826 * * *$ & $0.821 * * *$ & $0.873 * * *$ \\
\hline & $(-4.39)$ & $(-4.52)$ & $(-3.00)$ & $(-4.69)$ & $(-4.83)$ & $(-3.36)$ \\
\hline \multirow[t]{2}{*}{ District Assembly member } & 1.304 & 1.259 & 0.948 & $1.477^{* *}$ & $1.422^{*}$ & 1.084 \\
\hline & $(1.60)$ & $(1.36)$ & $(-0.30)$ & $(2.21)$ & $(1.96)$ & $(0.44)$ \\
\hline \multirow[t]{2}{*}{ Unit Committee member } & $1.488^{* *}$ & $1.474^{* *}$ & $1.362^{*}$ & $1.546 * * *$ & $1.527^{* * *}$ & 1.307 \\
\hline & $(2.53)$ & $(2.45)$ & $(1.75)$ & $(2.73)$ & (2.63) & (1.49) \\
\hline \multirow[t]{2}{*}{ Traditional leader } & 0.849 & 0.803 & 0.834 & 0.919 & 0.872 & 0.943 \\
\hline & $(-0.86)$ & $(-1.13)$ & $(-0.87)$ & $(-0.45)$ & $(-0.71)$ & $(-0.29)$ \\
\hline \multirow[t]{2}{*}{ Opinion leader } & $1.583 * * *$ & $1.554^{* * *}$ & $1.394^{* *}$ & $1.626 * * *$ & $1.589 * * *$ & $1.461 * *$ \\
\hline & $(2.92)$ & $(2.75)$ & $(2.08)$ & $(3.00)$ & $(2.83)$ & $(2.40)$ \\
\hline Received information on & & 1.172 & & & 1.163 & \\
\hline revenue management & & $(1.13)$ & & & $(1.15)$ & \\
\hline Knowledge of institutions & & 0.883 & & & 0.879 & \\
\hline (dummy) & & $(-0.90)$ & & & $(-0.95)$ & \\
\hline Knowledge of revenue & & 1.137 & & & 1.141 & \\
\hline management & & $(0.97)$ & & & $(1.00)$ & \\
\hline Satisfaction with & & & $2.324 * * *$ & & & $2.176 * * *$ \\
\hline government & & & $(15.16)$ & & & $(13.86)$ \\
\hline Observations & 2,869 & 2,862 & 2,779 & 2,910 & 2,903 & 2,818 \\
\hline Number of disricts & 120 & 120 & 120 & 120 & 120 & 120 \\
\hline
\end{tabular}

Notes: Table shows odd ratios for ordered logistic regressions. All specifications include regional dummies. S.e. are clustered at the district and electoral area level. T-statistics in parentheses. $* * * p<0.01$, ** $p<0.05, * p<0.1$. 
Supplementary Appendix Table SA8. Rights perception, ordered logistic estimations of the models in SA3

\begin{tabular}{|c|c|c|c|c|c|c|c|c|c|c|c|c|}
\hline \multirow{2}{*}{ VARIABLES } & \multirow{2}{*}{\multicolumn{3}{|c|}{$\begin{array}{cc}(1) & (2) \\
\text { Local leaders right to revenues }\end{array}$}} & (4) & (5) & (6) & (7) & (8) & (9) & (10) & (11) & (12) \\
\hline & & & & \multicolumn{3}{|c|}{ Own right to benefits } & \multicolumn{3}{|c|}{ Right to demand information } & \multicolumn{3}{|c|}{ Right to demand better handling } \\
\hline \multirow[t]{2}{*}{ Female } & 0.885 & -0.053 & -0.095 & 0.885 & 0.852 & 0.969 & $0.498 * * *$ & $0.513^{* * *}$ & $0.541 * * *$ & $0.516 * * *$ & $0.521 * * *$ & $0.554^{* * *}$ \\
\hline & $(-1.18)$ & $(-0.50)$ & $(-0.89)$ & $(-0.47)$ & $(-0.61)$ & $(-0.13)$ & $(-4.45)$ & $(-4.22)$ & $(-3.86)$ & $(-4.37)$ & $(-4.27)$ & $(-3.79)$ \\
\hline \multirow[t]{2}{*}{ Urban district } & 1.101 & 0.092 & 0.089 & 0.939 & 0.956 & 0.938 & 0.849 & 0.853 & 0.865 & 0.931 & 0.940 & 0.947 \\
\hline & $(1.06)$ & $(1.00)$ & $(0.98)$ & $(-0.32)$ & $(-0.23)$ & $(-0.31)$ & $(-1.12)$ & $(-1.07)$ & $(-0.98)$ & $(-0.47)$ & $(-0.40)$ & $(-0.36)$ \\
\hline \multirow[t]{2}{*}{ Education level } & $0.951 * * *$ & $-0.068 * * *$ & $-0.042^{* *}$ & 1.057 & $1.080^{*}$ & 1.064 & $1.141 * * *$ & $1.129 * * *$ & $1.129 * * *$ & $1.146 * * *$ & $1.144^{* * *}$ & $1.137 * * *$ \\
\hline & $(-2.65)$ & $(-3.31)$ & $(-2.20)$ & (1.43) & (1.79) & $(1.62)$ & (4.07) & (3.57) & (3.84) & $(4.32)$ & $(4.00)$ & (4.18) \\
\hline \multirow[t]{2}{*}{ Oil or mining nearby } & 1.022 & 0.021 & -0.033 & 1.367 & 1.403 & 1.368 & 1.018 & 1.037 & 1.175 & 1.096 & 1.143 & 1.292 \\
\hline & $(0.18)$ & $(0.17)$ & $(-0.25)$ & $(1.13)$ & (1.19) & $(1.10)$ & $(0.08)$ & $(0.16)$ & $(0.76)$ & $(0.38)$ & $(0.54)$ & (1.08) \\
\hline \multirow[t]{2}{*}{ Radio ownership } & $1.448^{* *}$ & $0.363 * *$ & $0.397 * *$ & $0.360 * * *$ & $0.376 * *$ & $0.447 * *$ & $0.483 * *$ & $0.495^{* *}$ & $0.596 *$ & $0.436 * * *$ & $0.452 * * *$ & $0.520 * *$ \\
\hline & $(2.23)$ & $(2.19)$ & $(2.27)$ & $(-2.69)$ & $(-2.57)$ & $(-2.10)$ & $(-2.57)$ & $(-2.47)$ & $(-1.83)$ & $(-2.77)$ & $(-2.63)$ & $(-2.16)$ \\
\hline \multirow[t]{2}{*}{ TV ownership } & 0.901 & -0.121 & -0.070 & 0.729 & 0.744 & 0.835 & 1.040 & 1.033 & 0.989 & 1.036 & 1.041 & 1.009 \\
\hline & $(-0.91)$ & $(-1.04)$ & $(-0.60)$ & $(-1.14)$ & $(-1.06)$ & $(-0.65)$ & $(0.20)$ & $(0.17)$ & $(-0.06)$ & (0.19) & $(0.21)$ & $(0.05)$ \\
\hline \multirow{2}{*}{ Mobile phone ownership } & 0.884 & -0.145 & -0.123 & 1.012 & 1.022 & 1.165 & 1.074 & 1.078 & 1.257 & 0.841 & 0.838 & 0.930 \\
\hline & $(-0.54)$ & $(-0.64)$ & $(-0.53)$ & $(0.03)$ & $(0.05)$ & $(0.34)$ & $(0.22)$ & $(0.23)$ & $(0.71)$ & $(-0.49)$ & $(-0.50)$ & $(-0.21)$ \\
\hline \multirow[t]{2}{*}{ Political interest } & $0.885^{* * *}$ & $-0.125 * * *$ & $-0.103 * * *$ & $1.128 * *$ & $1.147^{* *}$ & $1.170^{* * *}$ & 1.016 & 1.022 & 1.021 & 1.064 & 1.076 & 1.054 \\
\hline & $(-3.66)$ & $(-3.69)$ & $(-3.09)$ & $(2.16)$ & $(2.44)$ & $(2.62)$ & $(0.31)$ & $(0.42)$ & $(0.40)$ & $(1.26)$ & $(1.46)$ & $(1.03)$ \\
\hline \multirow[t]{2}{*}{ District Assembly member } & 1.212 & 0.154 & 0.124 & $8.581^{* * *}$ & $9.791 * * *$ & $6.706 * * *$ & $10.456 * * *$ & $10.866 * * *$ & $9.605 * * *$ & $9.662 * * *$ & $10.415^{* * *}$ & $9.176 * * *$ \\
\hline & $(1.18)$ & $(0.98)$ & $(0.76)$ & $(5.08)$ & (5.19) & $(4.47)$ & $(5.78)$ & $(5.83)$ & $(5.55)$ & $(5.85)$ & (5.97) & $(5.64)$ \\
\hline \multirow[t]{2}{*}{ Unit Committee member } & $2.234^{* * *}$ & $0.787^{* * *}$ & $0.689 * * *$ & 1.237 & 1.253 & 0.928 & $2.110 * * *$ & $2.097 * * *$ & $1.843^{* *}$ & $2.091 * * *$ & $2.080 * * *$ & $1.800 * *$ \\
\hline & $(6.02)$ & $(5.87)$ & (4.94) & $(0.72)$ & $(0.74)$ & $(-0.25)$ & (3.03) & $(2.95)$ & $(2.36)$ & $(2.93)$ & $(2.85)$ & $(2.26)$ \\
\hline \multirow[t]{2}{*}{ Traditional leader } & $2.254^{* * *}$ & $0.819 * * *$ & $0.806^{* * *}$ & $32.041 * * *$ & $35.532 * * *$ & $30.836 * * *$ & 0.985 & 1.023 & 0.929 & 1.099 & 1.174 & 1.052 \\
\hline & (5.59) & $(5.46)$ & (5.55) & $(3.44)$ & (3.56) & $(3.41)$ & $(-0.06)$ & (0.08) & $(-0.27)$ & $(0.33)$ & $(0.55)$ & (0.17) \\
\hline \multirow[t]{2}{*}{ Opinion leader } & 0.974 & -0.027 & -0.066 & 0.783 & 0.826 & 0.708 & 0.818 & 0.851 & $0.746 *$ & 0.815 & 0.857 & 0.753 \\
\hline & $(-0.22)$ & $(-0.22)$ & $(-0.52)$ & $(-1.08)$ & $(-0.82)$ & $(-1.57)$ & $(-1.19)$ & $(-0.93)$ & $(-1.69)$ & $(-1.22)$ & $(-0.89)$ & $(-1.65)$ \\
\hline \multirow{2}{*}{$\begin{array}{l}\text { Received information on revenue } \\
\text { management }\end{array}$} & & 0.043 & & & 0.800 & & & 1.008 & & & 0.881 & \\
\hline & & $(0.45)$ & & & $(-0.95)$ & & & $(0.04)$ & & & $(-0.71)$ & \\
\hline \multirow[t]{2}{*}{ Knowledge of institutions (dummy) } & & $0.345^{* * *}$ & & & 0.907 & & & $1.417^{* *}$ & & & $1.342 *$ & \\
\hline & & (3.47) & & & $(-0.46)$ & & & $(2.20)$ & & & $(1.88)$ & \\
\hline \multirow[t]{2}{*}{ Knowledge of revenue management } & & -0.017 & & & 0.734 & & & $0.712^{*}$ & & & $0.669 * *$ & \\
\hline & & $(-0.19)$ & & & $(-1.23)$ & & & $(-1.96)$ & & & $(-2.48)$ & \\
\hline \multirow[t]{2}{*}{ Satisfaction with government } & & & $0.087^{* *}$ & & & $1.487^{* * *}$ & & & $1.164^{* * *}$ & & & $1.128 * *$ \\
\hline & & & $(2.62)$ & & & $(4.95)$ & & & $(2.63)$ & & & $(2.01)$ \\
\hline Observations & 3,394 & 3,384 & 3,259 & 3,400 & 3,390 & 3,263 & 3,388 & 3,378 & 3,251 & 3,390 & 3,380 & 3,253 \\
\hline Number of disricts & 120 & 120 & 120 & 120 & 120 & 120 & 120 & 120 & 120 & 120 & 120 & 120 \\
\hline
\end{tabular}


Supplementary Appendix Table SA9. Individual behaviour, full sample; logistic estimations of models in SA4

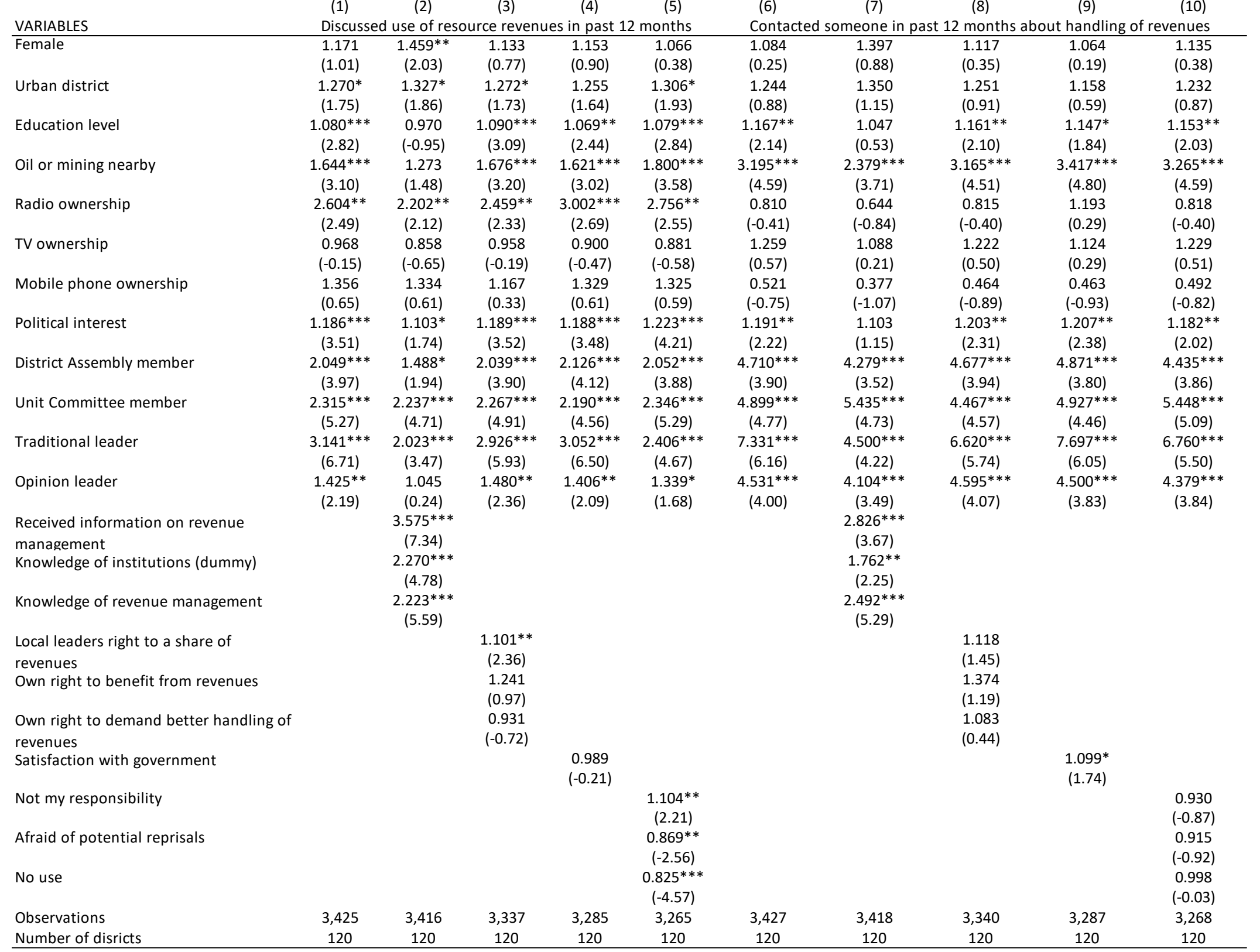

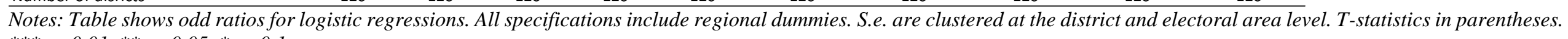
$* * * p<0.01$, ** $p<0.05$, * $p<0.1$. 
Supplementary Appendix Table SA10. Individual behaviour, leaders; logistic estimations of models in SA5

\begin{tabular}{|c|c|c|c|c|c|c|c|c|c|c|c|c|c|c|c|}
\hline \multirow{3}{*}{$\begin{array}{l}\text { VARIABLES } \\
\text { Female }\end{array}$} & \multicolumn{5}{|c|}{ UC member discussed revenue use with peers in past 12 months } & $\begin{array}{c}\text { (6) } \\
\text { DA member }\end{array}$ & $\begin{array}{c}\text { (7) } \\
\text { discussed re }\end{array}$ & $\begin{array}{l}\text { (8) } \\
\text { enue use with }\end{array}$ & $\begin{array}{c}\text { (9) } \\
\text { peers in pa: }\end{array}$ & $\begin{array}{c}\text { (10) } \\
\text { st } 12 \text { months }\end{array}$ & \multicolumn{5}{|c|}{ 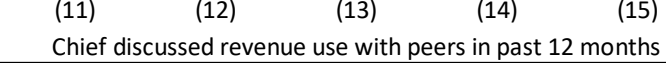 } \\
\hline & 0.764 & 0.777 & 0.961 & 0.879 & $0.627 *$ & & & & & & 0.776 & 1.561 & 0.560 & 0.816 & 0.894 \\
\hline & $(-1.12)$ & $(-1.01)$ & $(-0.17)$ & $(-0.44)$ & $(-1.88)$ & & & & & & $(-0.21)$ & $(0.41)$ & $(-0.57)$ & $(-0.17)$ & $(-0.09)$ \\
\hline \multirow[t]{2}{*}{ Urban district } & $1.443 *$ & 1.360 & 1.452 & 1.301 & $1.776 * *$ & 0.867 & 0.891 & 0.882 & 0.981 & 0.858 & 1.195 & 1.114 & 1.307 & 1.184 & 1.304 \\
\hline & (1.75) & (1.50) & (1.62) & (1.23) & (2.61) & $(-0.89)$ & $(-0.69)$ & $(-0.74)$ & $(-0.11)$ & $(-0.98)$ & (0.52) & $(0.31)$ & $(0.76)$ & $(0.47)$ & $(0.77)$ \\
\hline \multirow[t]{2}{*}{ Education level } & 0.937 & 0.912 & 0.946 & 1.006 & 0.951 & $1.368^{* * *}$ & $1.398^{* * *}$ & $1.374^{* * *}$ & $1.360^{* * *}$ & $1.329 * * *$ & 0.977 & 0.876 & 0.980 & 0.988 & 0.938 \\
\hline & $(-1.25)$ & $(-1.66)$ & $(-1.01)$ & $(0.09)$ & $(-0.83)$ & $(6.07)$ & (6.50) & (6.35) & (5.95) & $(5.23)$ & $(-0.34)$ & $(-1.53)$ & $(-0.28)$ & $(-0.17)$ & $(-0.93)$ \\
\hline \multirow[t]{2}{*}{ Oil or mining nearby } & $2.154^{* * *}$ & $1.910^{* * *}$ & $1.999 * * *$ & $2.288^{* * *}$ & $1.994^{* * *}$ & $3.363 * * *$ & $3.107^{* * *}$ & $3.384^{* * *}$ & $3.473^{* * *}$ & $3.510^{* * *}$ & $2.726 *$ & 1.727 & $2.837^{*}$ & $3.051^{*}$ & $3.151^{*}$ \\
\hline & $(4.31)$ & (3.49) & (3.42) & (3.88) & (3.27) & $(8.80)$ & $(8.21)$ & (8.36) & (8.99) & (8.70) & (1.78) & $(0.93)$ & $(1.86)$ & (1.97) & (1.97) \\
\hline \multirow[t]{2}{*}{ Radio ownership } & 1.113 & 1.125 & 1.035 & $0.513^{* * *}$ & 1.035 & 0.866 & 0.665 & 0.600 & 1.397 & 0.759 & 1.786 & 1.589 & 1.705 & 1.683 & 1.822 \\
\hline & $(0.45)$ & $(0.47)$ & $(0.12)$ & $(-2.79)$ & $(0.12)$ & $(-0.15)$ & $(-0.48)$ & $(-0.54)$ & $(0.31)$ & $(-0.30)$ & $(0.77)$ & $(0.60)$ & $(0.68)$ & $(0.68)$ & $(0.77)$ \\
\hline \multirow[t]{2}{*}{ TV ownership } & 0.628 & 0.623 & 0.631 & 0.949 & 0.560 & 0.696 & 0.733 & 0.694 & 0.603 & 0.700 & 2.268 & $2.313^{*}$ & 2.145 & 2.311 & 2.232 \\
\hline & $(-1.22)$ & $(-1.21)$ & $(-1.13)$ & $(-0.11)$ & $(-1.37)$ & $(-0.52)$ & $(-0.49)$ & $(-0.55)$ & $(-0.75)$ & $(-0.49)$ & (1.48) & $(1.66)$ & $(1.36)$ & (1.51) & $(1.37)$ \\
\hline \multirow[t]{2}{*}{ Mobile phone ownership } & & & & & & & & & & & 2.582 & 1.931 & 2.994 & 2.627 & 2.379 \\
\hline & & & & & & & & & & & (1.18) & $(0.80)$ & $(1.36)$ & $(1.23)$ & $(1.09)$ \\
\hline \multirow{2}{*}{ Political interest } & $1.176^{* * *}$ & $1.148^{* *}$ & $1.156^{* *}$ & $1.107^{* *}$ & 1.106 & 1.008 & 0.967 & 1.024 & 0.976 & 1.038 & $0.741^{* *}$ & $0.681^{* * *}$ & $0.739^{* *}$ & $0.738^{* *}$ & $0.732^{* *}$ \\
\hline & $(2.63)$ & $(2.08)$ & $(2.12)$ & $(2.08)$ & $(1.47)$ & $(0.10)$ & $(-0.45)$ & $(0.32)$ & $(-0.30)$ & $(0.46)$ & $(-2.44)$ & $(-3.30)$ & $(-2.43)$ & $(-2.29)$ & $(-2.55)$ \\
\hline Received information on revenue & & 1.090 & & & & & $2.396^{* * *}$ & & & & & 1.086 & & & \\
\hline management & & $(0.30)$ & & & & & (3.89) & & & & & $(0.21)$ & & & \\
\hline \multirow[t]{2}{*}{ Knowledge of institutions (dummy) } & & 0.807 & & & & & 0.899 & & & & & 1.563 & & & \\
\hline & & $(-0.94)$ & & & & & $(-0.45)$ & & & & & $(0.84)$ & & & \\
\hline \multirow[t]{2}{*}{ Knowledge of revenue management } & & $1.718^{* *}$ & & & & & $0.758^{*}$ & & & & & $2.495^{* *}$ & & & \\
\hline & & (2.59) & & & & & $(-1.76)$ & & & & & (2.27) & & & \\
\hline \multirow{2}{*}{$\begin{array}{l}\text { Local leaders right to a share of } \\
\text { revenues }\end{array}$} & & & $1.315^{* *}$ & & & & & $1.286^{* * *}$ & & & & & $1.419^{* *}$ & & \\
\hline & & & (2.25) & & & & & (3.56) & & & & & $(2.06)$ & & \\
\hline \multirow[t]{2}{*}{ Own right to benefit from revenues } & & & $1.149 * *$ & & & & & $0.624^{* * *}$ & & & & & & & \\
\hline & & & $(2.09)$ & & & & & $(-2.77)$ & & & & & & & \\
\hline Own right to demand better handling & & & 1.142 & & & & & $1.494^{* *}$ & & & & & 1.033 & & \\
\hline of revenues & & & (1.25) & & & & & (2.21) & & & & & $(0.15)$ & & \\
\hline \multirow[t]{2}{*}{ Satisfaction with government } & & & & $1.229^{* *}$ & & & & & $1.366^{* * *}$ & & & & & 1.072 & \\
\hline & & & & (2.44) & & & & & $(4.88)$ & & & & & $(0.46)$ & \\
\hline \multirow[t]{2}{*}{ Not my responsibility } & & & & & 1.116 & & & & & $1.238^{* * *}$ & & & & & 0.889 \\
\hline & & & & & $(1.60)$ & & & & & (3.91) & & & & & $(-0.96)$ \\
\hline \multirow[t]{2}{*}{ Afraid of potential reprisals } & & & & & $1.277^{* * *}$ & & & & & 0.968 & & & & & 0.928 \\
\hline & & & & & (3.64) & & & & & $(-0.65)$ & & & & & $(-0.22)$ \\
\hline \multirow[t]{2}{*}{ No use } & & & & & $0.787^{* * *}$ & & & & & $0.812^{* * *}$ & & & & & 0.819 \\
\hline & & & & & $(-3.42)$ & & & & & $(-4.69)$ & & & & & $(-1.14)$ \\
\hline Observations & 506 & 505 & 462 & 447 & 439 & 520 & 520 & 514 & 515 & 510 & 365 & 364 & 353 & 355 & 354 \\
\hline Number of disricts & 104 & 104 & 95 & 96 & 94 & 113 & 113 & 113 & 113 & 113 & 96 & 96 & 94 & 96 & 94 \\
\hline
\end{tabular}

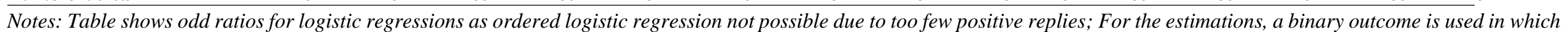

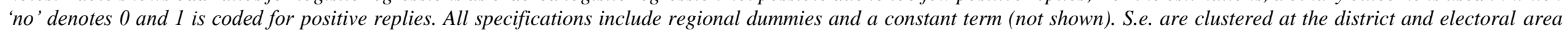
level. $T$-statistics in parentheses. $* * * p<0.01, * * p<0.05, * p<0.1$. 